\title{
Essays
}

\section{Èdè Àyàn: The Language of Àyàn in Yorùbá Art and Ritual of Egúngún}

\author{
Oláwọlé Fámúlè \\ University of Wisconsin-Superior \\ ofamule@uwsuper.edu
}

Kò sẹ́ní m’èdè Àyàn

Bí ẹní mú kọngọo ẹ lộwọ́

No one understands the language of Àyàn

Better than the drummer who holds the gong in his hand

Yorùbá maxim

From the Yorùbá oral historical, mythological, and ontological, abstract lines of reasoning, Àyàn is believed to be the first Yorùbá drum maker and drummer, who, after his death, was deified as the god of Drumming (Òrì̀̀à Àyàn, or simply Àyàn). Hence, when an experienced Yorùbá drummer plays his drum masterfully, the elders with the drum speech discernable ears (ọmọ̀ràn) that hear the drumming, even from afar commend, "may Àyàn, the god of drumming prosper/ protect you!" (Àyàn ó gbè ọ̣!)

As among other Yorùbá deities (òrișà) that live in the spiritual realm in certain but uncommon natural environments (forests, trees, rivers, streams, and mountains, among others), Òrị̀à Àyàn is thought to reside in wood (Villepastour 2015, 3). For this reason, Òrìsà Àyàn is emblematized by the wood with which the body of the drum (ilù) is carved. Similarly, this deity is eulogized as "the spirit who speaks out from inside his wooded abode" (Òrìnà gbénú igi fohùn), in reference to the log of wood with which the drums (ilù) are carved. It is said that Òrìnà Àyàn particularly prefers that ìlù be carved with Cordia millenii (igi ọmọ̀), a belief that gave birth to the Yorùbá saying, "out of the entire wood species of the forests is the preferred Cordia millenii, with which gbẹddu drum is carved" (Igi gbogbo ní ńbe nígbó, k'átó fi'gi ọmọ gbẹ gbẹdu). Because of his position as the patron deity of drumming, which 
by extension is used to accompanying sacred rites in honor of virtually all the Yorùbá òrișà, Òrị̀à Àyàn is thought to be their mouthpiece, as they all speak through the drums that he emblematizes. Another emblem of Òrìnà Àyàn that is even worshipped is a shallow hemispherical drum with a single fixed head, which is worn on the chest with a strap around the neck and beaten with leather straps held in each hand (gúdúgúdú) (Bascom 1952, 4). The gúdúgúdú symbol of Òrìsà Àyàn also goes by the praise name (oríki) "gúdúgúdú with its distinctive uneven and undulated back shape" (Gúdúgúdú, ab'ẹyin jákanjàkan). The component parts that formed this uneven and surged-back shape [of gúdúgúdú] include kúseré and apiràn. Kúseré is a circular metal object affixed onto the drum's wooded base, and apiràn is an array of wooden pegs that hold the kúseré securely onto the base of the instrument.

At the exoteric and practical level, Àyàn also refers to any Yorùbá traditional and professional drummer, who plays the drum (ìlù), often with the use of a gong (kọ̀ngọ́). The Yorùbá professional drummers share the name àyàn with Òrị̀à Àyàn since they are the human agents who play the drums (ìlù), emblem of Òrìsà Àyàn, and through which the deity speaks. The Yorùbá incantation "the day that the drummer drums with his gong/drumstick is the very moment that the Àyàn god of drumming speaks out that which is in his mouth" (Òojộ tí kọngoọ Àyàn bá f'ojú ba ilù ni Òrịsà Àyàn ńpọ t’ẹnu rẹ sílẹ) best illustrates the interconnection of the drummers (àyàn) with god of drumming, Òrìsà Àyàn. As succinctly corroborated by Amanda Villepastour, "the drummer in action becomes Àyàn."

Another Yorùbá term for a drummer (àyàn) is onilù. ${ }^{1}$ With their drumming (or drum music) that mimic the human speech, the Àyàn or Onílù verbalize words/speeches (ọrọ̣) that is or are intelligible to the ears of their patrons, often the dance performers (onijó). For that reason, ilù, to the Yorùbá, is an instrument that acts as a speech surrogate (i.e., substitute). That the Yorùbá refer to ìlù as "the talking drum" underscores this assertion. In fact, they strongly believed that if handled by a skillful drummer (àyàn/onilù), ilù, just like humans, can speak words or communicate effectively to those who understand the language of the drum. The Yorùbá phrase "a lifeless goat that speaks just like a human” (òkú-ewúrẹ tî́ fọ̀hùn bí ènìyàn), a euphemism for the goatskin fixed single- or double-headed hourglass drums that mimic human speech when drummed, is a testimony to ilù as a true "talking drum." Another Yorùbá saying that illustrates that ìlù is an instrument of language substitution is "that the gángan drum could speak in a human nasal tone of

1 Onílù is formed from two Yorùbá words oní and ìù (literally, "owner of the drum" or "one who plays the drum"), a euphemism for the drummer. Thus, anybody that plays drum is an onílù. But those Yorùbá traditional professional onílù, like the dùndún and bàtá drummers, are specifically referred to as àyàn. 
voice is not without the help of the drummer's own tip of the fingernails" (àti rán'mú gángan kò ș’èyin èékáná).

In Yorùbá traditional festivals, ritual performances, and religious practices in general, the role of àyàn--whose drumming or drum music imitate and code the natural language (Yorùbá), cannot be overemphasized. The Yorùbá aphorism "without drum music, there is no way to celebrate" (lái sílù, taní jẹ s'eré okúrùgbẹ!) is a testimony to the indispensable role of ilù in the context of traditional Yorùbá visual and performance arts. A clear example is the Yorùbá art and ritual of Egúngún, the theme of this study. Paradoxically, many Yorùbá art scholars often make very little or no effort to explore the relevance of ìlù in their studies on Yorùbá visual culture, such as Egúngún. This has continued to make it become virtually impossible for a deeper understanding of Yorùbá art in particular and African art as a whole. Ironically, the same scholars prefer to invest their energy, searching outside of the art's cultural origin to fulfil their primary goal of "appreciating" the African art, rather than searching within African culture, language and values, the very driving forces that gave rise to this art, and thus a catalyst to understanding it. $^{2}$ It is on that note that I believe the question that scholars of African art should begin to ask themselves is: when will African art scholarship--unlike Western art studies that often demand intellectual rigor and professional thoroughness--rise above its present art "appreciating" status vis-à-vis African art? In my opinion, as this present study is aimed at confirming, the understanding of African art critically requires that scholars be fluent or at least confident in the reading, writing, and speaking of the language of the people whose art they study.

Also heightening the problem of the lack of "understanding" of Yorùbá art is the very unique nature of it (as with other African art), in which an isolated work of art in context is a rarity. Thus, the present study examines the very indispensable roles of Àyàn drummers in the performance context of the annual Egúngún festival (ọdún Egúngún) in a Yorùbá community in Òkèigbó in Nigeria's Ondo State. As a native speaker with access to Yorùbá philosophy, values and history, and who is fully aware of the fundamental importance of language in African art studies, I aim in this study to examine the mutual relationship existing between the Àyàn and Egúngún from the vantage point of the Yorùbá language, the medium through which the said Yorùbá philosophy, values and history are stored and expressed. It delves into the very root of Egúngún within the Yorùbá cultural context, where traditions and history are preserved and recorded not in the western-type of writing, but rather in the Yorùbá language, ritual performance and ceremonies. It is hoped that this study will facilitate a deeper understanding of Egúngún along with the

2 Personal communication with Professor Rowland Abíodún on April 2, 2017. 
àyàn within the art and ritual performance context of the Odún Egúngún. The study illustrates the interconnection of the àyàn and Egúngún by first providing an overview of Yorùbá drums and their ritual contexts. This is followed by a close study of the Yorùbá ontological concept of Egúngún, one of the most valued patrons of Àyàn (the drummers), as an important form of Yorùbá religious beliefs and practices. Using the Egbẹ́ Òjẹ̀ (Cult of Egúngún) of the ancient Yorùbá town of Òkèigbó as a case study, the study concludes with an in-depth analysis of the role of Àyàn (Drummers) in Yorùbá art and ritual of Egúngún.

\section{An Overview of Yorùbá Drums and their Ritual Contexts}

Of all the Yorùbá traditional musical instruments, İlù (with single or double hourglass leather heads) are esteemed as the principal and most commonly used. The reason being that the ilu can be drummed with or without any other additional instruments to emitting or producing a given and distinctive piece of sacred or entertainment melody or rhythm. Appropriate examples include the àgbá and àgệrẹ (also àgẹreẹ-ògun), the sacred drum rhythms of the cult of Ogbóni--whose members worship Ile that is personified by the Earth goddess, and Ògún, their on and war patron deity. What is the meaning of ìlù and why is it so important particularly in the Yorùbá traditional religion's context? The Yorùbá word ilù is formed from two morphemes / $\grave{i}+l u ̀$ /, which is the short form of "the thing which is beaten?" (ohun tí a $n$ li) . However, the term ilù applies strictly to the log drums that have singleor double-hourglass goatskin/leather heads. Hence, there are several other Yorùbá musical instruments that are played but which do not bear the name ìù. Examples include trumpets (fèrèlkàkàkí), several types of gongs (agogo), and gourd/calabash rattles (șẹkệrẹ) that are rather called by their individual names, not ìlù. Depending on the types, ilù are typically played by the àyàn or onilù with sticks/gongs/drumsticks (igi/ kọngoọ), the palm or fist (àtẹlẹwộ/ ơwọ́), and twisted leather thongs (ọsán).

İlù can be placed into two main categories. In the first category are some distinct types of Yorùbá drums that are associated with the worship of òrì̀à, as they are used specifically in religious or ritual contexts. Hence, the term "drums for the deities" (ilù òrișà) is generally used to describe these drums' category. They are played by the drummers to produce or emit some distinctive individual òrișà's drumbeat (or drum music). Examples include the ìgbin, ìpèsè, àgẹrẹe, àgbá, ệù (also àgbé), and bàtá. Belonging to the second category are the drums that are used both for secular and religious music. These types of drums are played exclusively by professional drummers called àyàn. Dùndún drums are one such type. The following contains a discussion of these types of drums. 


\section{Ìgbìn}

Comprising of a set of four drums, igbin "are upright open-ended log drums with single leather heads fastened and tuned by wooden pegs" (Bascom 1953, 3). They are sacred to Ọbàtálá, the arch, superior òrì̀à. That Ọbàtálá is also called the great/superior deity (Òrìsà-Ńlá) leaves no doubt as to why he is regarded as "second in command to the Supreme Being" (Igbákejì-Olódùmarè). Another name that portrays Ọbàtálá as the most senior deity in the Yorùbá pantheon is "the chief/leader of all the òrìsà" (Ọbàtárìsà). As his name implies, Opàtálá is the ruler/god that is associated with white, which is a testimony to his pure/virtuous nature, persona, and attributes. For that reason, the devotees (especially the priests and priestesses) of Obàtálá are distinguished by their use of the white cloths and opaque white beads. They also paint their uncovered body parts (especially the head, face, and hands) with white pigment (made from ground kaolinite). The four-drum set of igbin comprises of ìá-igbin (or iyá-ńlá), the largest in the set, along with the second largest is ìá-gan (or jagba), as well as the third and the fourth smallest, keke and aféré, respectively. While the first two (iyá-igbin/ iyá-ńlá and iyá-gan/ jagba) are often played with a single stick and the palm or fist, the two smaller ones (keke and aféré) are usually played with two sticks known as ikeke-ilù. Each of the four drums is usually thick and squat and has three legs that are roughly carved out of the bottom of the drum on which they stand on the ground. That makes the ìgbin drum set an àgbé'lè-lì, as each igbin drum is drummed/played while secured on the ground with its three legs. The carvers of igbin often carved relief figures and other bas relief decorations on the sides. The igbin drum ensemble is played at the annual Ọbàtálá festival. ${ }^{3}$

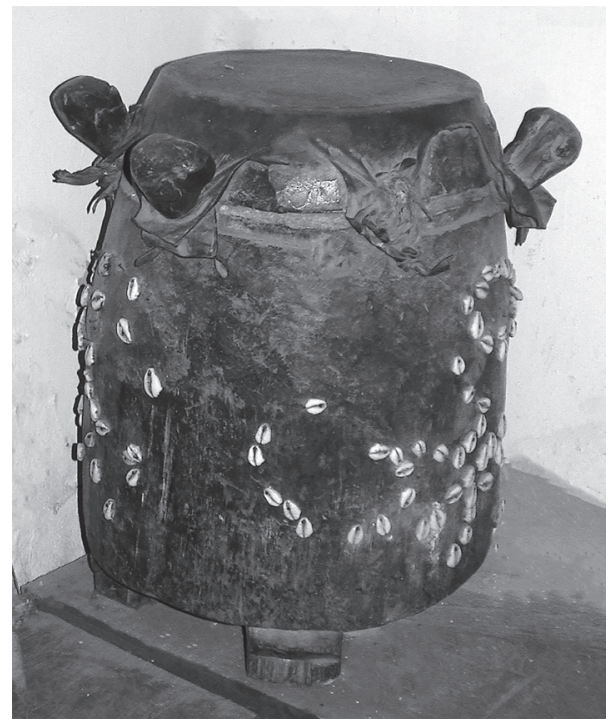

Figure 1: İyá İgbin

3 For further reading on ìgbìn, see Olu Daramola ati A. Jeje, Àwọn Àșà àti Òrișà Ilẹ Yorùbá (1967, 173-174); William Bascom, Drums of the Yoruba of Nigeria $(1953,3)$. 


\section{İpèsè}

İpèsè (also ìpèsi) is the drum ensemble of the ifá priests (babaláwo), which they play during the ifá festival (Odún-Ifá). The drums are also used at the burial rites of any of their members. The ìpèsè drum ensemble comprises of three drums, namely, ipèsè, the largest in the set, which can be up to six feet tall. Aféré, next to ipèsè in size, is about three feet tall but is wider than ipèsè, and finally àràn, the smallest in the set. Other musical instrument in the set used with the three drums is the iron gong/bell (agogo). Just like igbin drums, ipèsè are upright open-ended log drums with single leather heads fastened and tuned by wooden pegs. İpèsè, the largest drum in the ipèsè ensemble, is played with a single unshaped stick and the palm, while the two smaller drums (aféré and àràn) are played with two unshaped sticks.

\section{Àgèrè}

Also known as àgẹrẹ̀-ògún, the àgẹrẹ̀ drum ensemble is used by the hunter's guild (egbẹ-ọẹ) during important events, which include the hunter's dirge (irèmọjé), which is sung/chanted at a second burial ceremony ișípà (also isípà-ode), traditionally performed for any deceased hunter or hunters (ode or ọlọ́dẹ). Àgẹrẹ can also be played at other times, especially to honor Ògún, the Yorùbá iron and war patron deity (Drewal 1997, 219). Relevant examples of such occasions include the annual festival of the hunter's guild (Àjọ̀dún Ẹgbẹ́Odẹ) and the Ògún festival (Ọdún Ògún), when the àgệrẹ drum ensemble is played and all the members of the hunter's guild display their dancing steps. The àgệrẹ dance style itself is also called àgệrẹ or itasẹ-àgẹ̀rẹ. The àgệrẹ (or àgẹ̀rẹ-Ògún) ensemble comprises of three drums, namely, àgẹrẹ̣ (the largest), fééré (next in size to àgẹrè̀), and aféré (the smallest in the set). Like ipèsè and igbin, each of the three àgẹrẹ drums has a hollowed wooden body. The only difference is that àgẹrẹ̀ drums have two equally-sized hourglass goatskin/ leather heads (contrast to igbin and ipèsè with single-hourglass leather heads). Because they are double-headed drums of an enormous size, each àgẹrẹ drum is placed horizontally on the ground where it is being played.

\section{Àgbá}

Àgbá is the drum ensemble used in the cult of Ògbóni, a secret society that wielded strong political, judicial, and religious powers among the Yorùbá in the precolonial era, but now functions as a social and religious group. Called "Ògbóni society/group" (Egbẹ́ Ògbóni, or simply Ògbóni), the members worship Ilẹ̀, the Earth, which is personified by the Earth Goddess who is variously called “the Great Mother of the Earth" (İyá-Ayé, Àbẹnní Àdẹ̀, Ẹdan Òlóló, Poóyè, and Lánní Olọmọ, among others) (Famule 2003, 9). Like the ìgbin and 
ipèsè, each of the three-drum ensemble of àgbá is upright open-ended log drum with single goatskin/leather head. But unlike the igbin and/or ipèsè that are usually of moderate size, àgbá drums are generally large and heavy. This is the reason for which they are sometimes called a "large barrel" (àgbákẹrẹbẹtẹ́). J.R.O Ojo has also suggested that the term àgbá could be "a reference to the loud, cannon-like sound produced by some of the drums" (Ojo 1973, 50). I'm inclined to agree with Ojo's suggestion based on the following Oríki Ògbóni (the praise chant of the Ògbóni secrete society) that obviously validates his assertion: "children of Ògbóni, owner of the cannon-like drum that produced a roaring sound like that of a falling tree, just like the Àràn that is common in İjèșa/Iléșa" (Ògbóni Modùlorè, Omọ Alágbàá dún gbò bí igi; Àgbá dún-mi-dún; Àràn tìJèșà wá lù).

Àgbá drums usually have carvings with bas relief figures on the sides, which often include images of human face(s) with large eyes. The large eyes are a reference to the outsized eyes of Edan (also Edan Ògbóni), a pair of a male and female bronze figures joined at the top by an iron chain. Edan is one of the two principal emblems of Ògbóni. The other being Onílé, the "owner of the house/land", another pair of free-standing male and female bronze figures, but without the chain (Famule 2003, 26-29). The Onilé figures are always placed together on a special altar inside the Ògbóni lodge (ilédi) and treated as

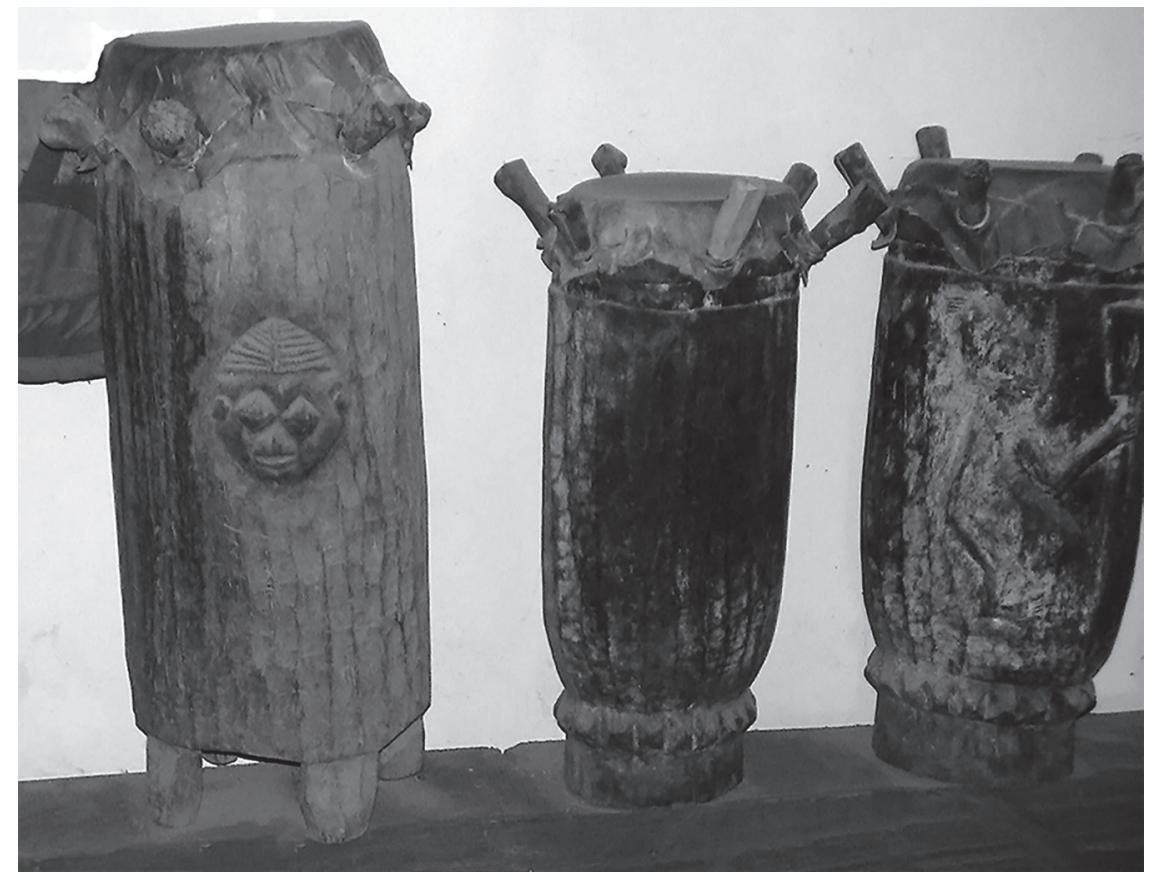

Figure 2: Àgbá drum ensemble 
one unit and referred to as İyá-Ayé, a euphemism for the Ògbóni Earth goddess. More importantly, both the Ėdan and Onilé bronze figures are depicted with a very large pair of eyes that often appear on the sides of the àgbá drums. These large eyes are a reference to the "all-seeing" and spiritually powerful eyes of İyá-Ayé. That the large eyes of the Ėdan and Onilé bronze figures that are also carved on the sides of the àgbá drums are an allusion to Ògbóni as a powerful goddess who uses her spiritual power to identify with accuracy people with antisocial behaviors and is always very hard on them, as evidenced in her praise song (oríki):

\section{Lánní Olomọ \\ İyá mi Àbẹní tí f'orí èké bù'kèlè \\ Àbẹní, Poóyè tí ń mù jẹ ộdàlè \\ Kanna-kánná abojú lágbárí \\ Abímọ sílẹ̀ Obinrin \\ Óp’ọdàlè pẹéepeẹé \\ Ộọ̀ buniwò s'ojú konko mọ́ni ${ }^{4}$}

\section{Lánní Ọlọmọ}

My mother Àbẹnní, who eats her food-morsels with the liar's severed head Àbẹnní is also Poóyè, who drinks the blood of perfidious person(s)

She is the very one whose large eyes cover the entire forehead

A born hard and fearless woman

She kills and utterly exterminates the treachery

The audacious Goddess that stares and stares menacingly at you. ${ }^{5}$

\section{Èkù (Àgbé)}

Èkù are the drums of ẹpa, a masking ritual festival found predominantly in eastern and northeastern parts of Yorùbáland, among the İjèșà, Èkìtì, İgbómìnà, and Okun Yorùbá, respectively (Famule 2017, 397). The ệkù ensemble comprises of three drums. The largest is the "mother of ẹkù" (İyá-ẹkù), the lead drum that produces a deep and overpowering pitch. İyá-ẹkù is a round pot-shaped clay drum with stretched goatskin hour glass head (Famule 2005, 171-172). Marsha Vander Heyden had observed this kind of clay drum also being played at the ẹlẹfọ́n (ẹpa) festival at İlọ́rọ-Èkìtì in 1970 (Heyden 1977, 19). Heyden indicated that the same type of clay drum, reported by Kenneth

4 This Oríki Ògbóni (a secret cult whose members worship Ile, which is personified by the Earth Goddess) was adapted from Àsàbíọjẹ̣ Afẹ́nápa (And Her Traditional Ifá/Òrị̀à Bata Musical Band), "Ogboni", In the Album "Isese Lagba" (Tradition and Culture Is the Best). Duration: 54:42 minutes (the "Ogboni” track is 7:01 minutes). October 11, 2007.

5 Translation by the author. 
Crosthwaite Murray, who called it àgbé, was also played at the epa festival at Òmù Àrán in 1931 (Heyden 1977, 19). The other two drums in ẹkù drum ensemble are omele-abo and omele-ako, both upright open-ended hollow log drums with a single leather head.

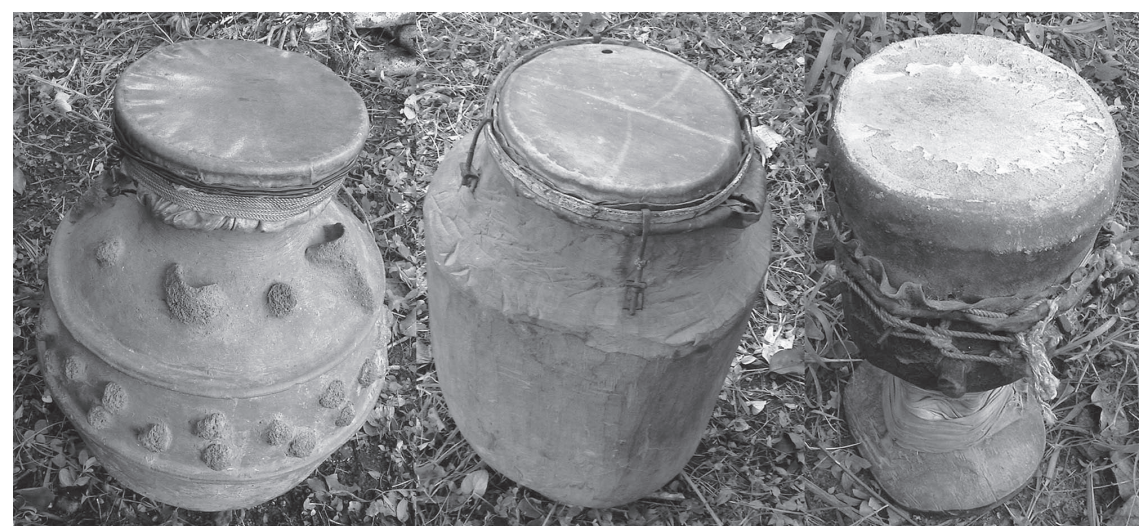

Figure 3: Ẹ kù drum ensemble

\section{Bàtá}

Bàtá drums are used only for religious music, especially in the cult of Sàngó, the god associated with thunder and lightning. It is said that when Șàngó was alive, he was believed to be a great magician who used the bàtá drum music as an important vehicle for his effective magic performance and acrobatic display. Thus, the Șàngó priests (oniṣàngó), who serve as the principal patrons of bàtá today, usually include displays of magic and acrobatic dance in their ritual performances. Bàtá drums are also used in the cult of Egúngún, especially in the magic and acrobatic dance performances by magic display/entertainer Egúngún (eégún onídán/aláré). For these reasons, Akin Euba has suggested that "bàtá is the preferred instrument in situations where magic is performed, and this can only be because its sounds are effective in magic making" (Euba 2011, 518).

Bàtá ensembles comprises of five to six drums, namely, "mother of the drum" (iyáàlu), a "female subordinate drum" (omele-abo), a "male subordinate drum" (omele-ako), a "subordinate drum" (kudi), and "a pair of two subordinate drums" (omele-méji), or "three subordinate drums tied together to function as a talking drum" (omele-mẹta). Each bàtá drum has a hollowed wooden body with two unequal sized heads (one smaller than the other) covered with a stretched and fasten goatskin leather. 


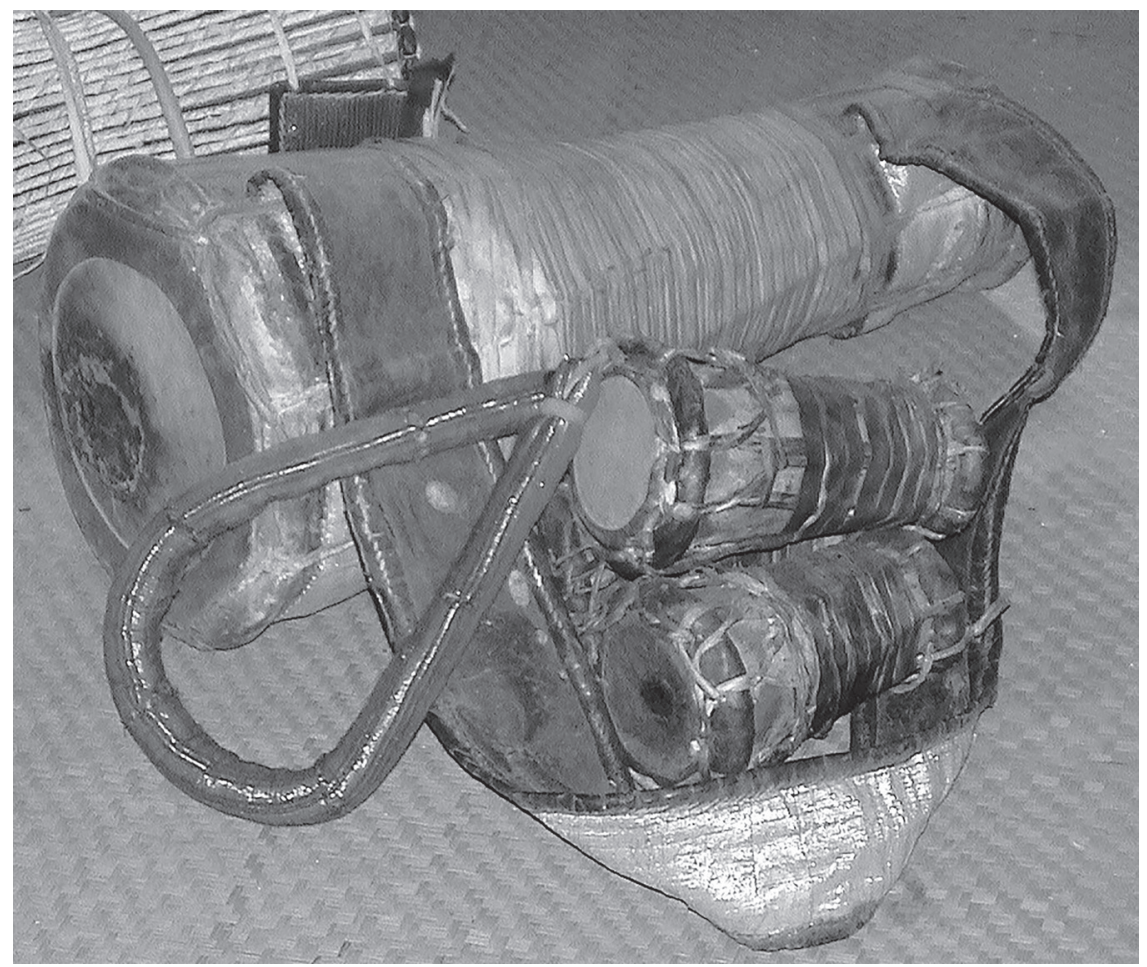

Figure 4: İyáàlù and Omele-méjì Bàtá

\section{Dùndún}

Dùndún drums are used both for secular and religious music. The dùndún ensemble comprises of five drums, namely, ìyáàlù, kẹríkẹrì, gángan, kànàngó, and gúdúgúdú. Except for gúdúgúdú, which has only one hourglass head, each of the four drums in the dùndún five-drum ensemble has a hollowed wooden body with two equal sized hourglass heads covered with stretched and fasten goatskin leathers. The iyáàlù is so referred to as such because is the largest in the set. The ojúgbe Small brass bells (ojúgbe), cast using the cire perdue method, are attached around the two hourglass heads of iyáàlù. The second largest drum in the dùndún ensemble is kẹíkẹri, literally, "enjoyable/satisfying", an allusion to it as adding sweetness to dùndún drum music. The second smallest is gángan, while kànàngó is the smallest of the four drums.

Gúdúgúdú, the fifth drum in the dùndún ensemble, is distinct from the previously mentioned four drums in the set not only because is the only one that has a single head, but also because it is characterized by ìda and kúseré. İda is a dark or black dried sap that is glued onto the center of the goatskin-covered hourglass head of gúdúgúdú. The ida component serves two 


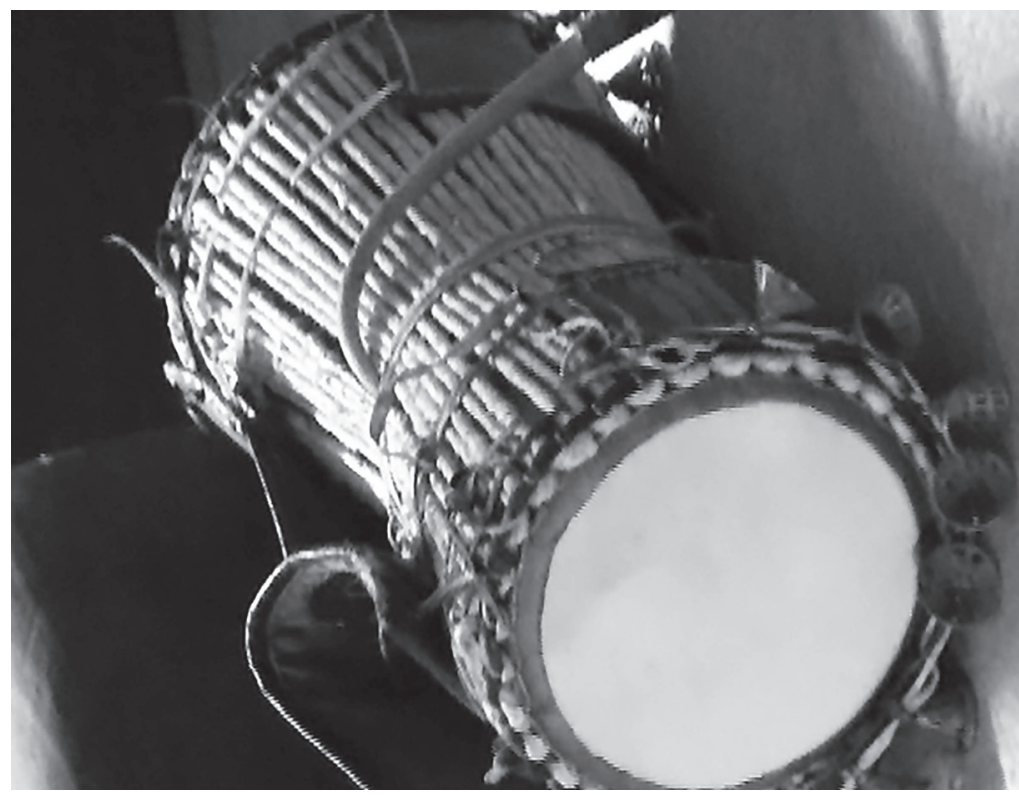

Figure 5: İyáàlù Dùndún

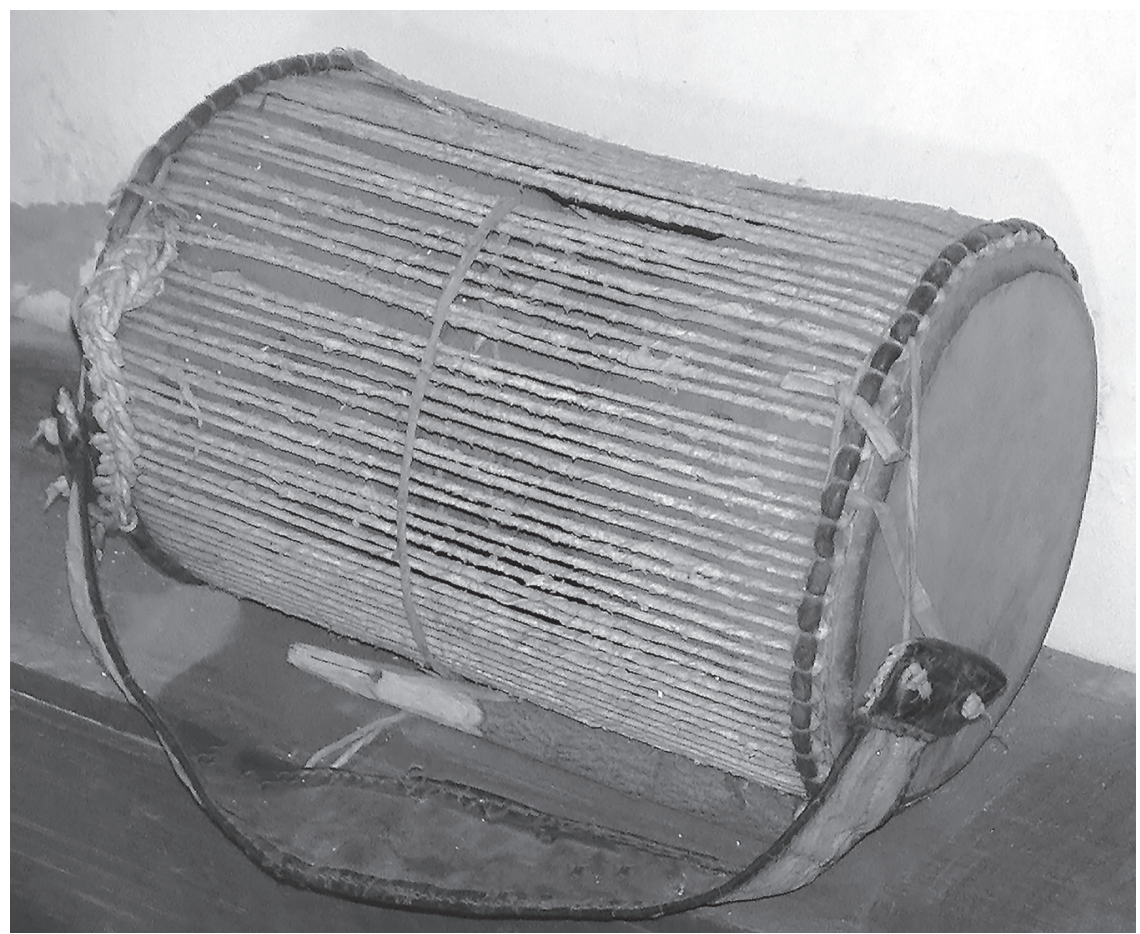

Figure 6: Kẹríkẹi Dùndún 
important functions. The first pertains to its spiritual connection to Ògún and one of the òrișà pantheons that the god of the drums (Òrìsà Àyàn) serves as their spokesperson. It is believed that the tree sap/latex (oje-igi) that comes out of a $\log$ of wood when it is either felled or carved with iron tools (the symbol of Ogun), is a form of ritual offering (ètùtù) to Ògún. Thus, one of the praise chants (oríki) of Ògún is the following: "the Ògún deity that is being worshipped by wood carvers is fond of drinking the tree sap" (Ògún gbẹnà-gbẹ́nà oje igi ló $n \mathrm{mu}$ ). The second and last function of ida, which is glued onto the center of the goatskin-covered hourglass head of gúdúgúdú, is acoustic--it allows the drum to produce two different musical tones when played, depending on where exactly the head of the drum is struck. Kúseré, the second distinctive and indispensable component by which gúdúgúdú is characterized, is a circular iron bar affixed beneath the base of the drum. Kúseré also alludes to Ògún , as it is said that without iron tools like adzes, chisels, or knives (the symbol of Ògún), the carvers of the drum's wooden body (igi-ilù), or any wood carvings for that matter, cannot perform their functions. Thus, the Yorùbá saying "any deities who disparage Ògún would roast their yam and find no knife to peel it" (Òrișà t'ó bá ní t’Ògún kòsí, yóó sun'su kò ní r’ộbe wo), an allusion to Ògún as indispensable to all the rest of the Yorùbá òrị̀à. And from the practical point of view, the kúseré component of gúdúgúdú "also helps to hold in place a series of wooden peg that are placed between it and the base of the hollowed wood body, helping to facilitate greater resonance" (Omojola 2010, 34).

In order to provide the reader with the necessary background knowledge to understand the specific and more in-depth role of àyàn in the performance context of the Egúngún festival (Odún Egúngún), the theme of this study, I will now provide a discourse on the Yorùbá concept of Egúngún.

\section{Egúngún: A Physical manifestation of the Yorùbá ancestor spirits}

Egúngún is thought of as a physical manifestation of the ancestor spirit(s). For that reason, every senior egúngún (Egúngún Àgbà) is addressed as "father/ ancestor" (bàbá). This belief is rooted in the Yorùbá concept of ìwà, which has been succinctly described by Rowland Abiodun as "the essential nature of a person or thing." (Abiodun 2014, 245). In this study, I broaden the concept of ìwà to covering the essence of human existence and including the ancestors, along with other spirit beings/deities. That makes iwà not defined solely in terms of physical life of an individual on Earth, but extends to the afterlife. The reason for this is that the Yorùbá strongly believe that the dead (óku), via their spirits, still exist after death. That also means that the human essence-or core values--can still influence the living even after death. Consequently, 


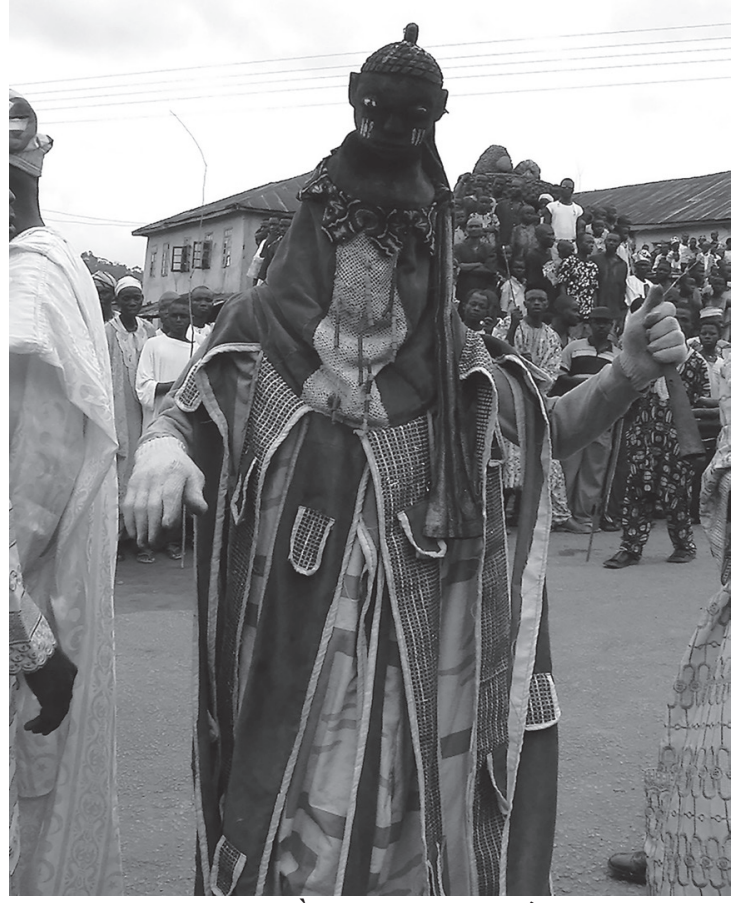

Figure 7: Ọṣ̣pà Egúngún Àgbà

the Yorùbá recognize two ìwà realities, namely, a good ìwà (ìà-rere) and a bad ìà (iwà-lásán). The former is a human existence with a positive essence/ core values, and the latter is a human existence without any positive essence or impact while alive. The Yorùbá term for a human continued existence and essence even after death is ẹhin-iwà, in which the dead continue to make "their presence [and essence] known to the living, whose well-being depends upon their relationship to the living dead" (Pemberton 1989, 175). Thus, at the demise of their parents, a common petition of the children would be "Our deceased parent, do not forget us as you rest peacefully in heaven; please continue to look back and watch over us" (Òkú ọlọmọ má sùn lọ́run; jọ̀wọ́ bojú w’èhin kío wá wòwá o).

The relationship existing between the Yorùbá concepts of ẹhìn-iwà (as discussed above) and egúngún, the major theme for this study, cannot be overstressed. Because ệhin-iwà provides a new status of "ancestor spirit," who is now enlisted in the realm of the òrișà, when an accomplished old person (i.e. one having iwà-rere) dies, his or her bereaved children eulogize him or her, saying "Our parent had transitioned to an òriṣà divinity, now to be worshipped on our knees” (Bàbá/ İyá wa ti d’Òriṣà àkúnlẹ bọ), a euphemism for 
a befitting worship. Hence, it is this concept of ẹhin-ìwà on which the Yoruba religious practice of ancestor veneration is based (Odún Egúngún being the most popular of these).

Morphologically, the Yorùbá term egúngún is a compound word formed by the combination of the morphemes /e+gún+gún/, literally, "that which facilitates or bring about stability, unity, peace, and joy," among others. Thus, in Yorùbá communities where the cult of egúngún is prevalent, the devotees perform Odún Egúngún annually, with one major expectation in mind--bringing about their wellbeing and promoting the community's harmony and stability. Egúngún devotees found this belief in the Odù Ifá, Ọwọ̀rìn-Asệyìn (also Ộọ̀rìn-Ṣẹ), ${ }^{6}$ which describes egúngún as sayégún, ${ }^{7}$ an allusion to egúngún as the ancestor spirits who bring about societal stability and people's wellbeing. The Odù Ộộrìn-Aséyin recalls that at a certain time when the Earth (ayé) was threatened with collapse, Ifá (also Ọrúnmilà) prescribed that a propitiatory ritual sacrifice (ẹbọ/ètùtù) be offered to the Supreme Being, Olódùmarè, whose abode is the spiritual world (Àjùlé-ọrun), so that he might stabilize ayé. Soon after the prescribed ẹbọ/ètùtù was brought to Olódùmarè, he sent down the heavenly spirit beings known as sayégún, the first egúngún, to help stabilize ayé. The sayégún/egúngún barely got to the world of the living (ilé-ayé), where they had their initial stopover in a forest that would later be called the forest-grove of egúngún (igbó-igbàlè), when rain started to fall. It was the orchestra of àyàn who with their drumming finally brought the egúngún home from their initial igbó-igbàlè stopover. From that day on, many egúngún, especially the egúngún-àgbà, have continued to use igbó-igbàlẹ as the grove from where they appear to the public during the Odún Egúngún. It was also since that time that the pacts between the egúngún and àyàn (who led them home with their drum music) together with babaláwo, who prescribed the ẹbọ/ètùtù, become effective. That pacts decree that, "it is forbidden for any egúngún to flog

6 Odù Ifá is an Ifá literary corpus passed down to the Yorùbá by Ọrúnmìlà and known as Ifá, the Yorùbá god of wisdom and divination. The Yorùbá history of the creation describes Ifá (also interchangeably called Ẹlà) as "a witness to creation and human destiny" (Elẹrií-ipín), an affirmation that the Òrìsà wa there to witness the creation of humankind and whereby every human chose his/her own destiny. Professor Rowland Abíodún has called Ifá literary corpus "the intellectual power-house" of the Yorùbá people in his audacious and ground-breaking book, Yoruba Art and Language: Seeking the African in African Art (2014). I will here add that Odù Ifá literary corpus is Yorùbá's recognized and accepted sacred book of knowledge on Yorùbá culture and history recorded in Yorùbá oral form, and which is retrievable only by those who fully understand Yorùbá language (speaking, writing, and reading) beyond an entry level.

7 Sayégún is derived from the morphemes /so+ayé+gún/, meaning "put/secure + the Earth/world of the living + in stable, perfect, or good shape." It is believed that the Yorùbá term egúngún was coined from sayégún. 
the drummers or the ifá diviners/priests" (Egúngún kò gbộdọ na Àyàn; bẹệni wọn kò gbọ́dọ na Babaláwo).

Another Odù Ifá source that confirms egúngún as heavenly spirits (AráÒrun), who descended from their heavenly abode to stabilize ilé-ayé, is found in Ogbè-Ròsùn (also Ogbè İròsùn):

Apárí awo Ẹgbá

Ọsọ̀sọ ni'run àgbọ̀n awo Ẹsà

Abasósó orí rààrì-raari awo Òde-İjẹbú

A dá fún Òlòlò-lóhùn tí șe ọkọ ọbuntun...

Nijộ tí àwọn Irúnmọlè àti àwọn Egúngún

Ńti ọ̀run bọ wá sí ayé. ${ }^{8}$

One with a baldhead, the secret of Ėgbá (Abẹókúta)

The one with a plentiful beard, the secret of Ẹsà

One with a large tuft of hair on the head, the secret of Òde-İjẹbú

It casts Odù Ifá for the Stutter/Stammer, husband of Ọbuntun

On the day the 400 high ranking divinities together with Egúngún

Are coming from heaven onto the earth.

However, the term egúngún is strictly used in two contexts. The first exemplifies those that are not perceived as "Ancestor." Thus, this type of Egúngún, which Ulli Beier has referred to as the "unserious masquerades," (Beier 1964, 191-2), is beyond the scope of this study. The egúngún in this category are interchangeably called "the masked player/entertainer" (egúngún aláré), "the masked performer of tricks/magic" (egúngún onídán); "we dance with the wood" (egúngún agbégijó), or "the itinerant masked dancer" (egúngún alárinjó). Egúngún alárinjó accurately describes this first type of egúngún, since they characteristically travel from one Yorùbá community or region to the next, performing dances, tricks, and magic at all times of the year, and living predominantly on the incomes of their performances.

The second type of egúngun, the focus of this study, exemplifies those that are recognized as "real" egúngún, alluding to a physical manifestation of the "Ancestor spirits." They are found among the Ọyọ́-Yorùbá and their descendants who migrated southwards to other Yorùbá towns like İgànná, Aáwẹ́, İsẹ́yìn, Ẹdẹ, İbàdàn, and Òkèigbó. Because of their Ọyọ́-Yorùbá origin, they are occasionally called Egúngún-Ọyộ. Unlike the first type (egúngún alárél

8 The Odú Ifá (Ogbè-Ròsùn) was adapted from Bascom, “Ogbè-Ròsùn.” In Ifa Divination: Communication between Gods and Men in West Africa $(1969,208)$. 
onídán/agbéiijó/alárinjó), the Egúngún-Ọyọ́ type incorporates those that specifically connect with Ancestor veneration. Hence, they are also called "the inhabitants of Heaven" (Ará-ọrun), or "the Ancestors" (Bàbá). This type of egúngún emblematizes the spirit of the dead (aged) man, who is believed to have transformed into an ancestor in ẹ̀hin-iwà.

Through egúngún, the ancestor spirit manifests under a specially created shroud-costume assemblage called ẹkúlagọ that is worn to cover the head and the whole body of the arệku, the human agent that donned the ệkúlagọ. There are different forms of ẹkú/agọ, each depending on its component materials. Some are made entirely of traditionally hand-woven kijipá cloths and tightly crocheted netting (àwọn) sewn around to the face, which veils the face of the arệkú. The Eégún Alágọ type from Òkèigbó exemplifies this form of ẹkú/agọ. Some are made of layers of clothes of different colors (especially red, yellow, and blue colors) and potentially with such attachments as animal skulls and

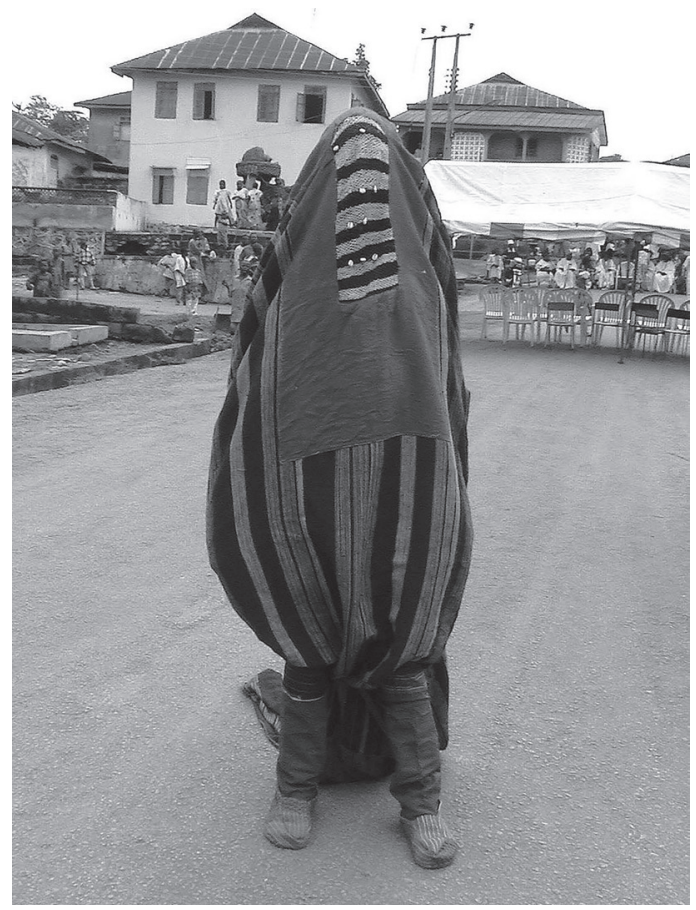

Figure 8: Eégún Alágọ

horns and leather pouches of medicine-charms.

Some others are made of a variety of wild animals' pelts, potentially with ère carved headpieces. An ideal example is the Aláwọpálà. 


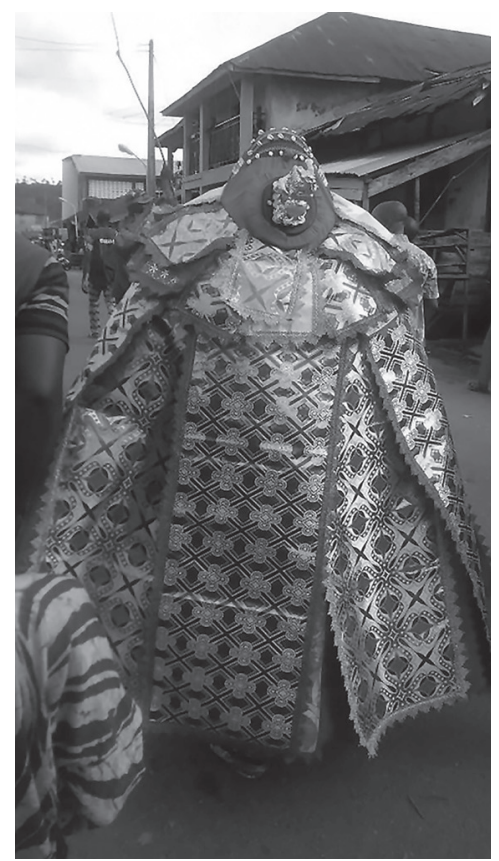

Figure 9: İtíàrán

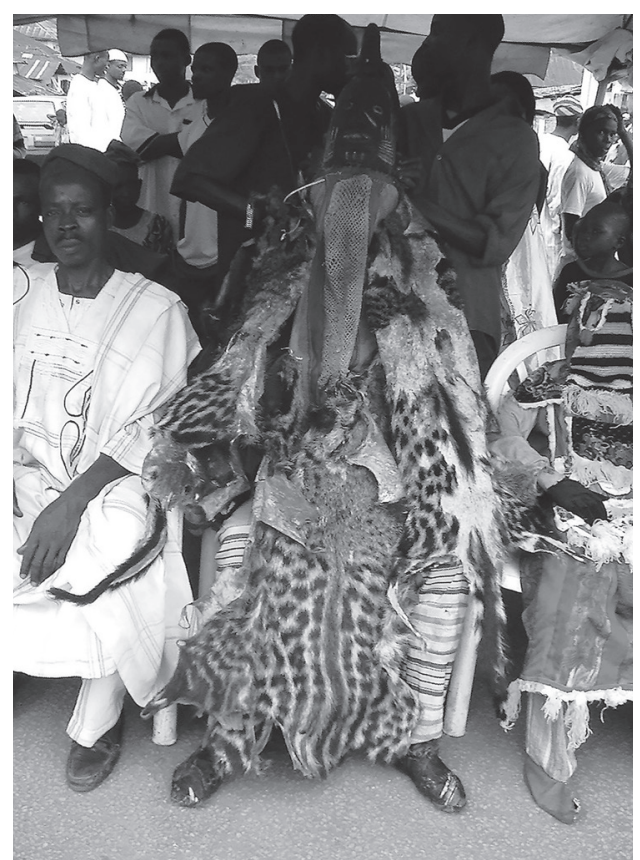

Figure 10: Aláwọpálà

The primary purpose of ẹkúlagọ is to totally obliterate the identity of the human agent that dons it, in order to conceal the power that gave form to the "Ancestor spirit" through the wearer of the ẹkú (arẹkuú), the energizer of the ẹkú lagọ. Hence, from the esoteric or mystic level, the real meaning of egúngún is "powers concealed." That is, the voluminous ệkúlagọ of egúngún, the manifested "Ancestor spirit," has concealed the unknowable, that which is knowable only to the members of the egúngún cult (mọríwo/ọjẹ). This arcane implication is persuasive in the following ẹsà or iwì egúngún: "egúngún is not that which can be seen; the ancestral spirit is unknowable in the forest-grove of egúngún" (Egúngún kò s' ẹni àárí; Òoṣà ò sệni àámọ nígbàlẹ). ${ }^{9}$ And even among the mọríwo/ọjẹ̀, who have access to igbó-igbàlè--where egúngún usually dress up before emerging to the public, and thus, know the "powers concealed" in egúngún--they are forbidden to reveal the secrets about the "powers concealed." That the moriwo are bound to adhering strictly to this pact is contained in their cult's slogan, reminding them of the impending deadly consequence(s), should they divulge the cult secrets to any non-initiates: "the lips of the knowledgeable ones or cult's initiated members must

9 Èsà/iwì egúngún are praise songs or chants of egúngún. The same is also known as "head praising" (oríki), when it applies to an individual Yorùbá family or lineage's praise names or songs. 
always remain gagged" (wíwo lẹ́nu awo ń wo), a euphemism and reminder that all the moríwo must forever guard all the cult's secrets from all who are not initiated into the cult.

As earlier explained that the Yorùbá thought about "ancestor spirits" is deeply rooted in their concept of ìwà with ệhin-iwà, that concept also informed their religious practice of ancestor veneration/worship, the most popular being the Odún Egúngún. Hence, the Yorùbá believe that their deceased ancestors never die; rather, they relocate to another world, which is the spiritual realm of spirit beings (ọrun), from where their spirits can be invoked and appear in the form of egúngún. Upon the invocation of the spirits of the dead (often by way of the Odún Egúngún), the ancestor(s) of the family-lineage of

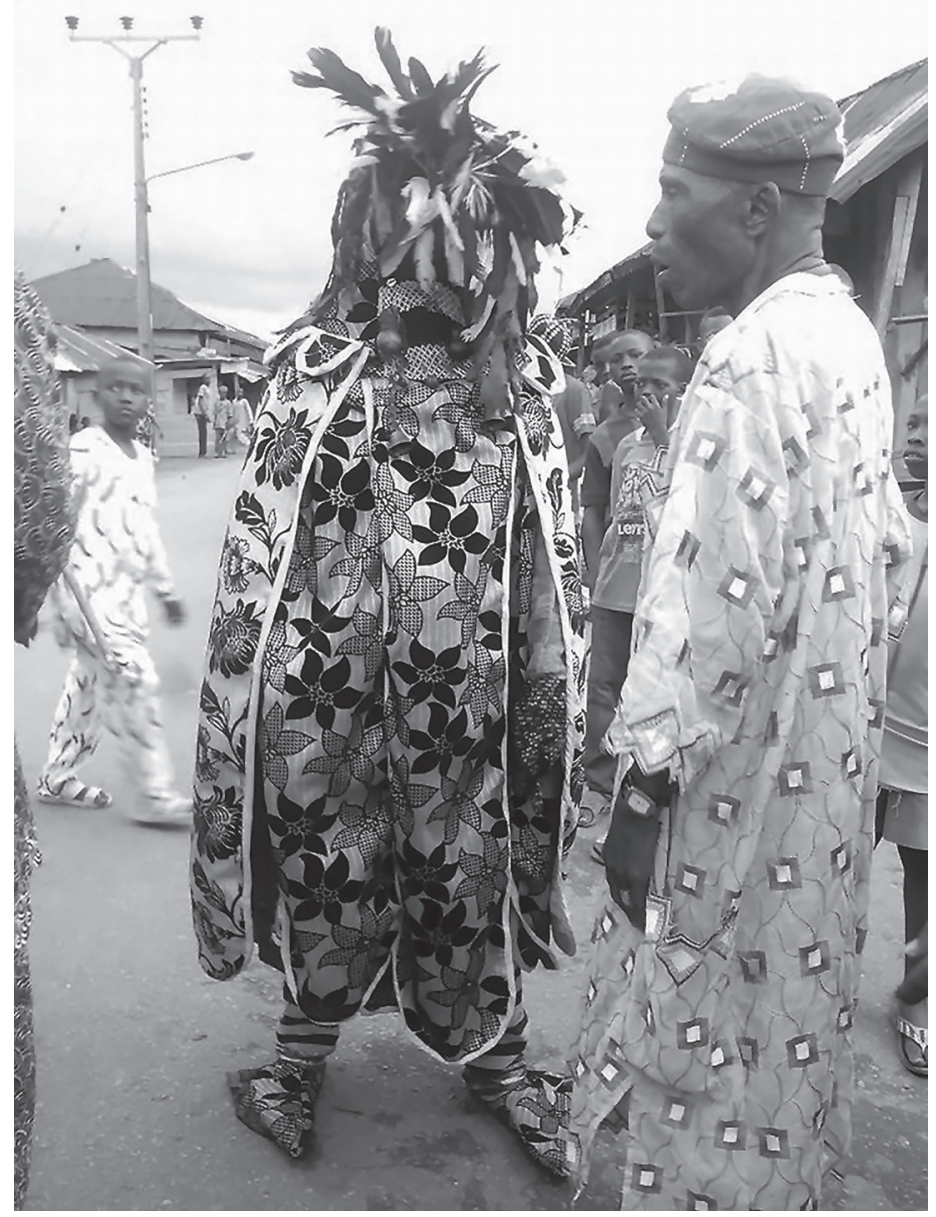

Figure 11: Eyẹ Abidíàlè (Also see Figure 7) 
egúngún manifest physically in the appearance of egúngún that is addressed as Bàbá/Bàbá Àgbà, an allusion to the Ancestor or Ancestor spirit.

\section{Performance Context of Odún Egúngún}

The author has analyzed the Odì Ọwọ̀rìn-Asẹ́yin (also Ộwọ̀rìn-Ṣẹ́), which reveals that the first egúngún, known as sayégún, were the spirit beings that Olódùmarè sent from their heavenly abode to come and bring soothe to the chaotic ilé-ayé; and which also tells that the àyàn were the ones who led the first egúngún home from igbó-igbàlè with the drumming. However, it is important to also stress that since then, the unending role of the àyàn in the cult of egúngún has been unabated. Hence, the following is a narrative that points to the further indispensable role of àyàn in the performance context of Odún Egúngún, which were based on the author's own eyewitness accounts for over the last two and half decades that he has been researching on the Odún Egúngún in Òkèigbó. ${ }^{10}$

Òkèigbó is a historic town located in Ilệ-Olújí/Òkèigbó Local Government, in the Ondó State of Nigeria. It is a major town (from which İfẹtẹ̀dó sister-town was formed in 1931) along the ancient cities of Ilé-Ifẹ̀ and Ondó. Of all the major traditional festivals that are celebrated at Òèigbó, which

10 That I have been researching the Odún Egúngún in Òkèigbó and elsewhere in Yorùbáland hitch-free for over two and half decades is not because I am smart. And neither is it simply because I come from the İgbórí family lineage Egúngún. The Yorùbá say "Ėnìyàn ló ńbe lẹ́yin Orò ni Orò fi ńké" (Bullroarer, the emblem of Òrìsà Orò - a nocturnal deity that is acclaimed for neutralizing the witches power - is emitting the sacred voice of Orò only because there are people behind the deity that spin/ swirl the emblem). It is on that note that I would mention the following Ọjẹ// Mọríwo (Egúngún devotees and cult members), who have been so kind to let me have the unlimited access to their families' Ilérun, Awésàn /Ojúbọ Egúngún, and Igbó-ìgbàlẹ. This wonderful people have also continued to provide me all the "insider perspectives" on the rites of Egúngún. They include High Chief Olu Babajide (the Alápìnńi Òjè of Òkèigbó), Chief Adesope Igbalade (Eldest son of Baba Igbalade, the late Aláàgbáà of Òkèigbó), Chief Àwíșe Adérẹ̀mí Fágbadé (Current Aláàgbáà of Òkèigbó), Chief Ògúnníyì Ògúnkànmí (Current Eésọ̀run Ọjẹ of Òkèigbó), Chief Adedinni (the former Aláàgbáà of Òkèigbó), Chief Asọjjẹ̀ (the late Aláàgbáà of Òkèigbó), Baba Israel Oloyede, aka Folly (the Àwòrò-Arẹkú of Egúngún Abídogun), Baba Oyeyemi Adetunji Ajarogungbo (the custodian of his family Egúngún Arọ́batẹ, İpẹ́, and İkòtó), Chief Gbemibade Akinromade (the Ọbaláșe/Baálẹ Onílù-Àyàn of Òkèigbó and İfẹ́tẹ̀dó), Mr. Sunday Ọjẹ́dìran (Son of Baba Òjẹ́dìran, the late Aláàgbáà of Òkèigbó), Bàbá Ọlọ́pàádé (Head of the Badà Eșùbí Egúngún lineage-family), and Mr. Olaosebikan Ọlọ́pàádé (Member of the Badà Eșùbí Egungun lineage-family). Others include the current three female Ọjẹ̀ Chieftaincy title holders of the İyálájé Ọjẹ of Òkèigbó, İyá-Mọdẹ Òjjẹ of Òkèigbó, and the most senior female Òjẹ̀ Chieftaincy title İyá-Àgan of Okèigbó. There are many more people/ informants that are too numerous to list here, but whose contributions to this study are immeasurable. I thank you all from the bottom of my heart. 
include Ọdún Ògún (also Olọ́jọ́), Orò, Àlúkú, among others, Ọdún Egúngún, in which the role of Àyàn cannot be overemphasized, is the most popular and always best attended.

Like other Yorùbá communities where this form of Ancestor veneration is prevalent, the cult of egúngún Òkèigbó is known as ọjẹ (or ẹgbẹ ọjeè). And the cult members are referred to as "those with the secret knowledge of the egúngún cult/ọjẹ (moríwo). They are all in charge of and the partakers of Odún Egúngún, which is celebrated every year in that community. The title holders among the òjẹ include the chief priest of egúngún (aláàgbáà). He is also eulogized as "the father of moriwó" (Baba Mọíwó), an allusion to aláàgbáà being the spiritual head of the mọríwó. The current aláàgbáà of the egúngún cult in Òkèigbó is Chief Àwíșe Adérẹmí Fágbadé. Next in rank to

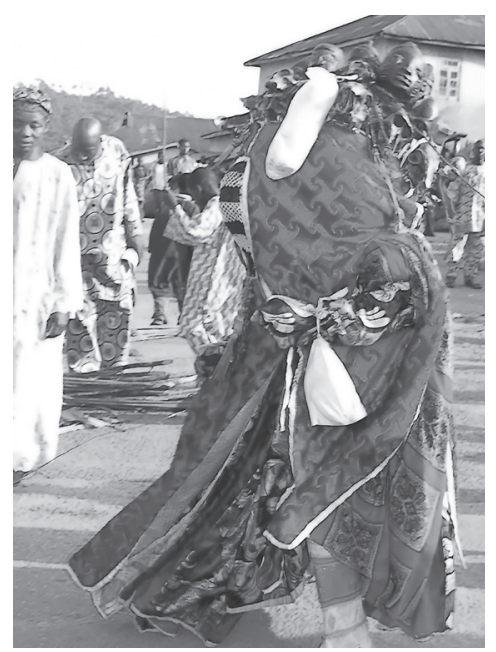

Figure 12a: Etíyẹí

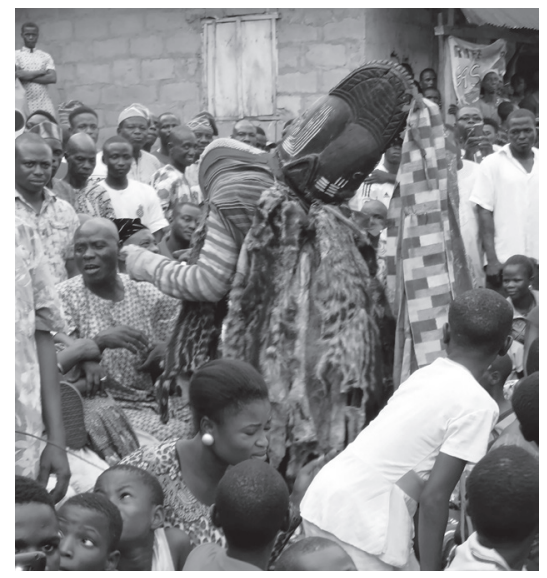

Figure 13: Aláwọpálà

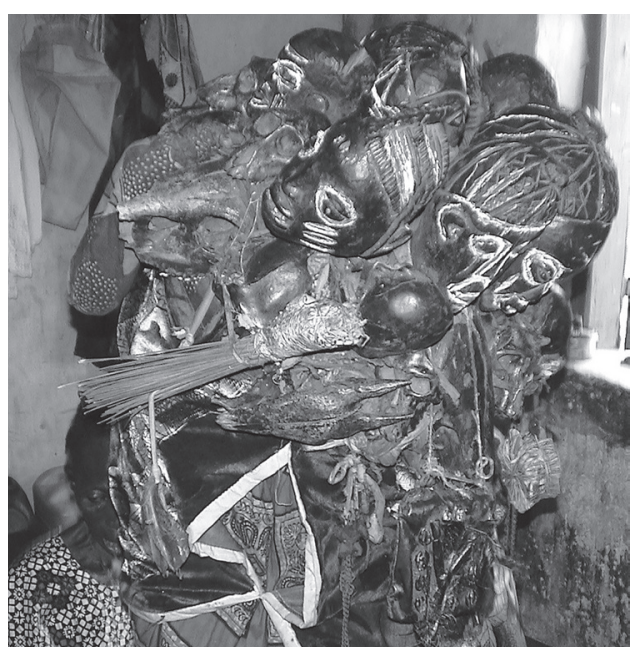

Figure 12b: Etíyẹí close view

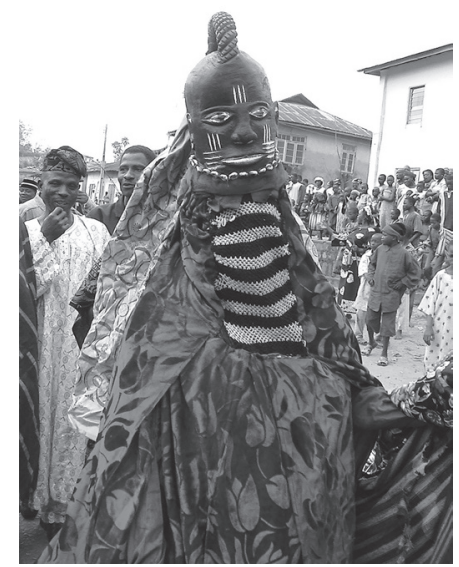

Figure 14: Arọ́ba 
Èdè Àyàn: The Language of Àyàn in Yorùbá Art and Ritual of Egúngún

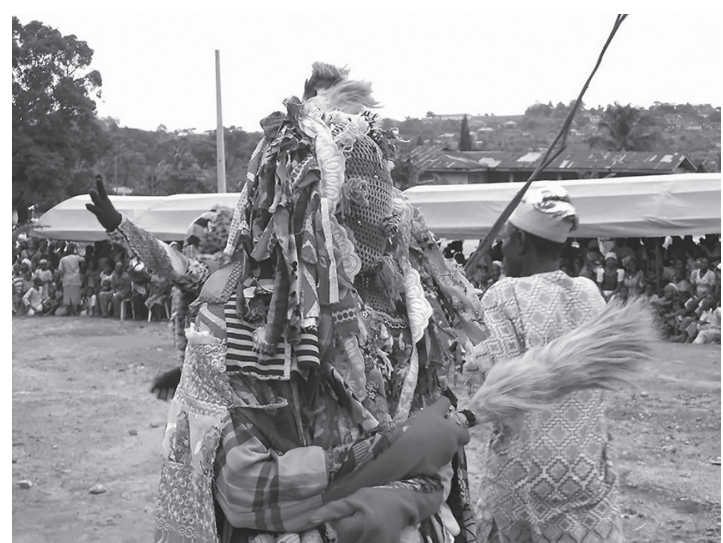

Figure 15: Owólẹwà

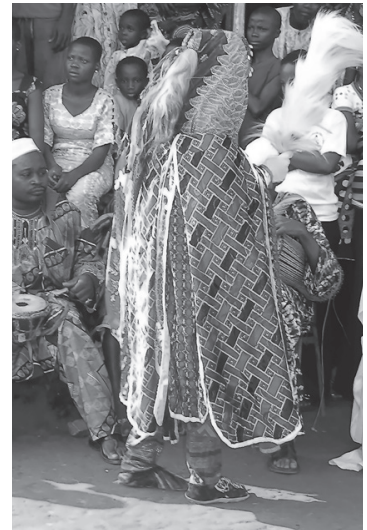

Figure 16: Adáradóhùn
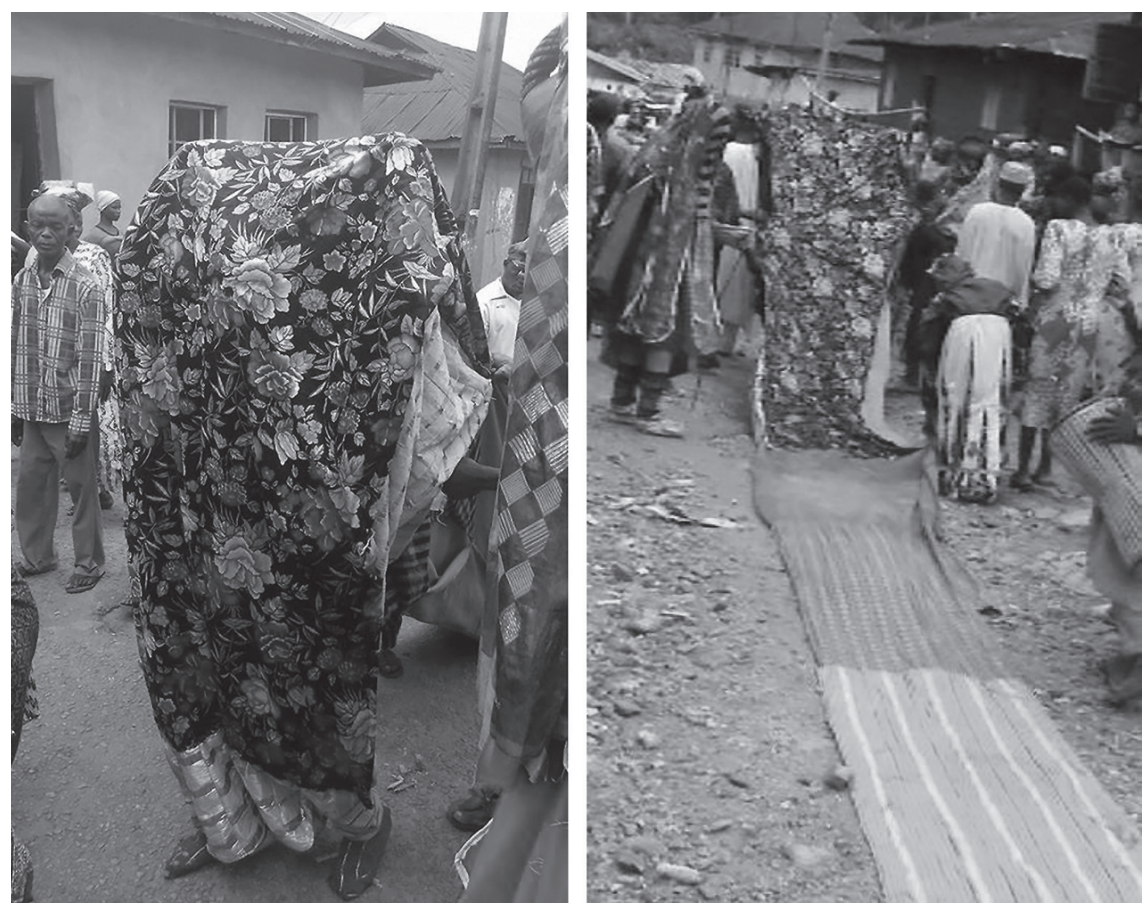

Figure $17 a-b$ : Badà front and back views 


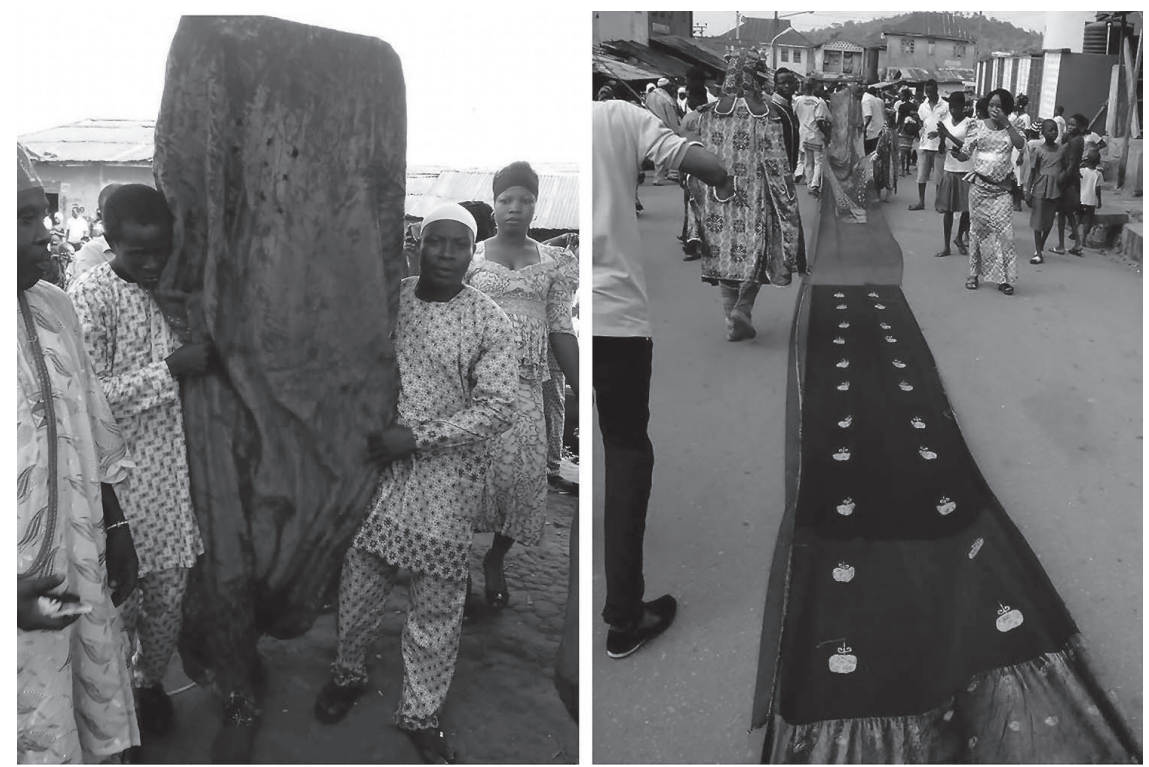

Figure 18a-b: Kúlé front and back views

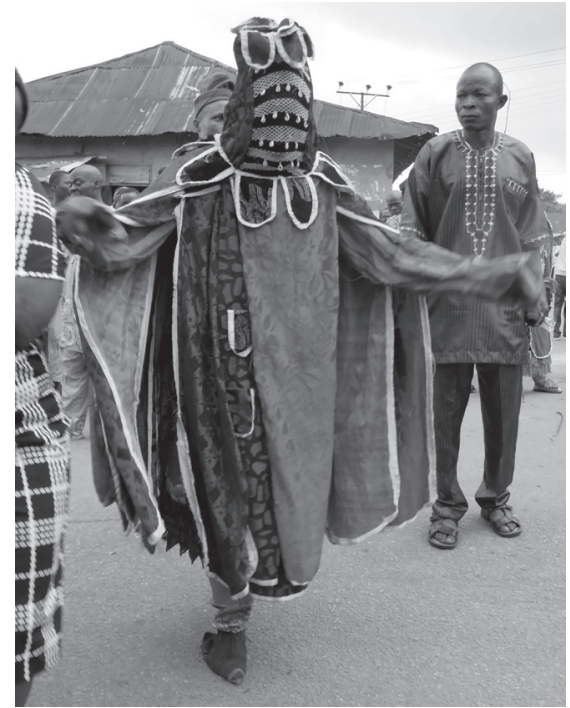

Figure 19: Eégún Òkèàgbè

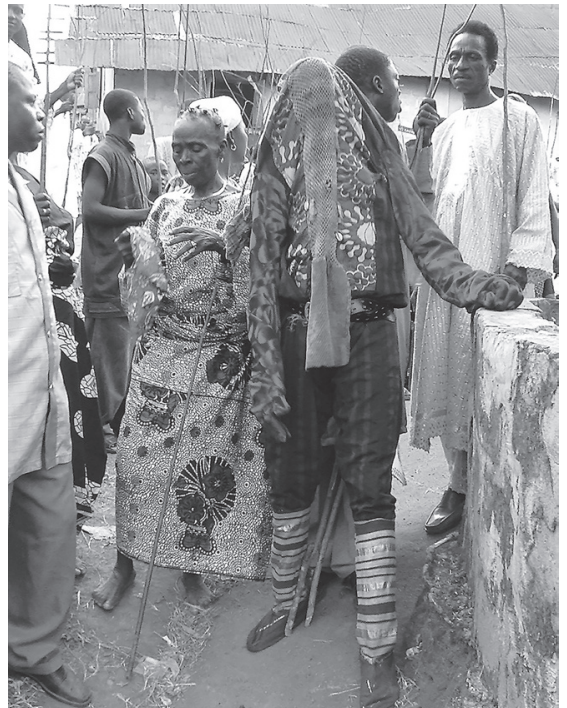

Figure 20: Awó 


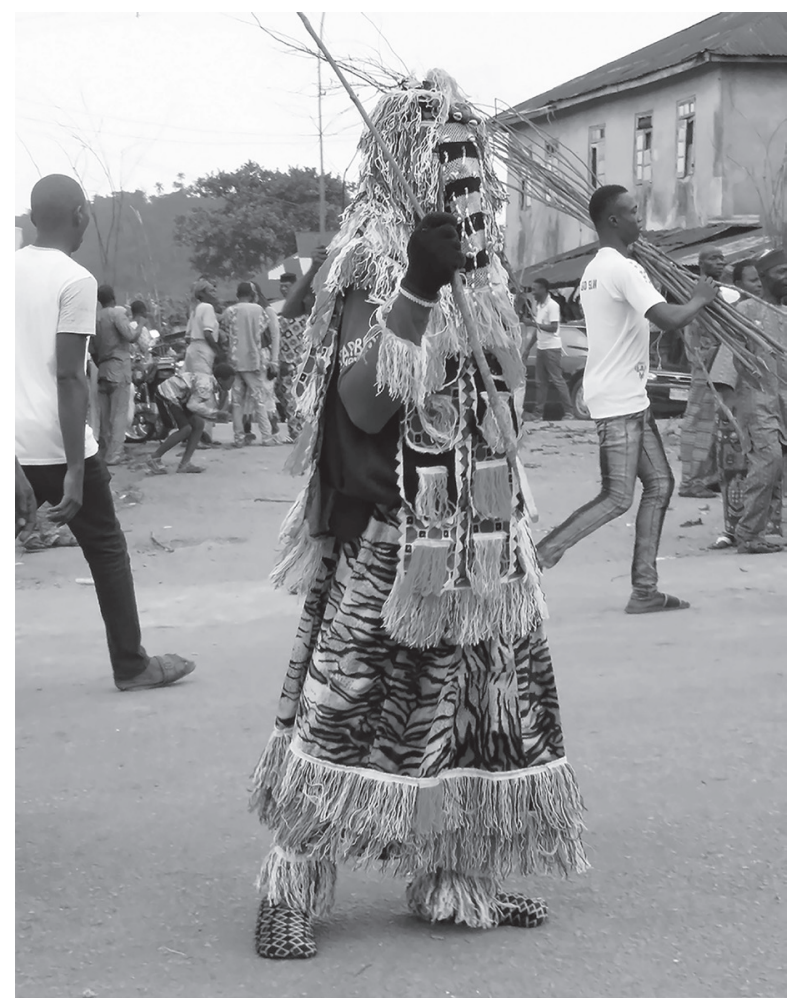

Figure 21: Mọlérí

the aláàgbáà is eésọ̀run ọjẹ̀, which is held by Chief Ògúnníyì Ògúnkànmí. As well, there are three female ọjẹ̣ chieftaincy titles, which include, in descending order of rank, ìá-àgan, ìyá-mọdè, and iyá-lájé.

There are various types of egúngún in Òkèigbó, which can be loosely identified or distinguished using two variables. The first variable is identification by the ẹkúlagọ type of egúngún. Hence, this identification variable is based principally on the physical appearance and formal-style attributes of an individual egúngún. Falling within this first variable are egúngún with the carved mask/figure headdresses (egúngún-elére), or egúngún with a load on their head (egungun-ẹlẹrù), a euphemism for the carved mask/figure(s) and other assemblages of objects that adorn the headdresses of certain egúngún. Those "load" assemblages often include deer antlers (iwo-àgbọnnín), sacred animal skulls (agbárí-ẹranko abàmi), small gourds filled with magical or medicinal substances (àdó/ìrẹ̀rẹ̀), leather pouches of medicines (gbinrín-oògùn), and carved masks/figures (ère), among others. Egúngún Etíyẹrí, Aláwọpálà, and Arọ́batẹ are typical examples of the egúngún ẹlẹrùlelére type. Also identified or distinguished by their ệkúlagọ shroud-costume type are the egúngún with 
headdress made of an animal tail or hide and skin (egúngún-onírọrọ̣). Relevant examples are egúngún Owólẹwà and Adáradóhùn. Some other egúngún that are identified by their costume types are egúngún with large and royally designed shroud-costumes, part of which often trail behind the egúngún (egúngún-alágọ gbáruru). The examples are egúngún badà and kúólé. Others located within this costume type variable are egúngún with a tray or cap-like design pattern headdress (eégún-alátẹ), egúngún with a tight-fitting shroud (egúngún-èdó), and egúngún without any particular headdress design/shape (egúngún-òkolombo)

The second and last variable used to determine a given egúngún Òkèigbó type is identification by the function, character, and/or performance traits of an individual egúngún. Thus, there are warrior egúngún (egúngún-ológun), ex-

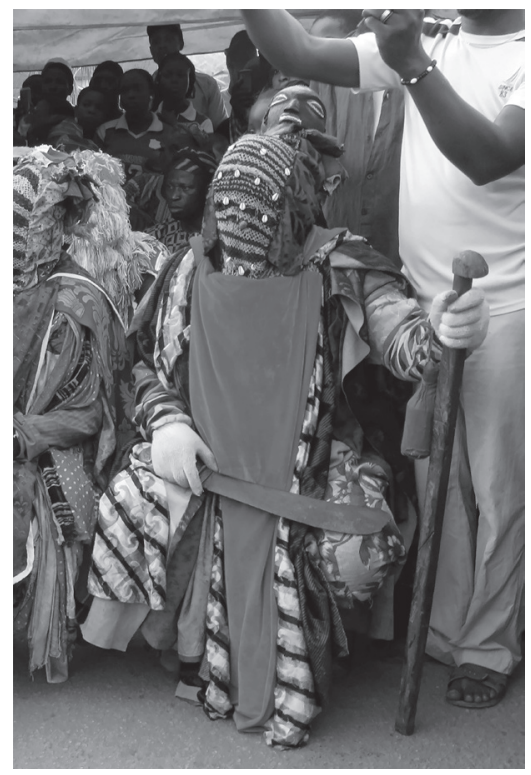

Figure 22: Arọ́batè

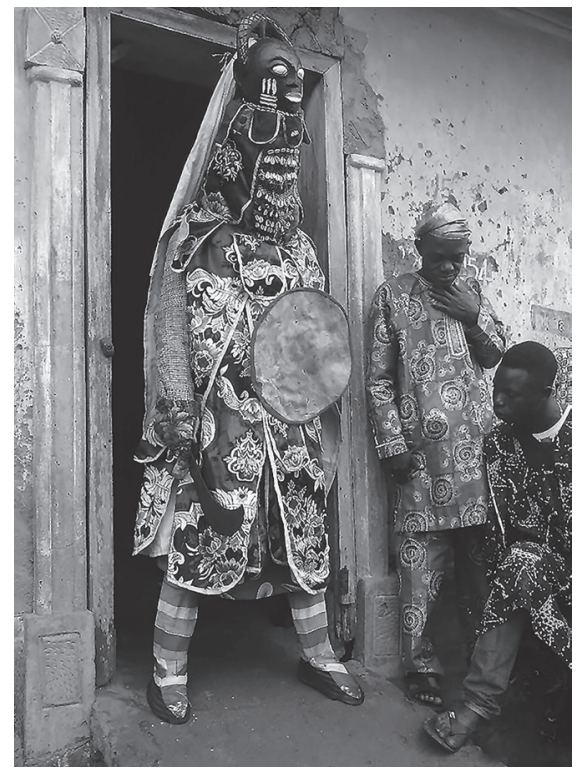

Figure 23: Akingbadé

amples of such being Arọ́batẹ̀, and Akíngbadé, that are distinguished by the weaponries or missiles (swords, axes/ mattocks, machetes, clubs, etc.), which they brandish in their hands. Others are the "children provider" (egúngúnolọmo), "provider/maker of herbal medicines and concoctions (administered to children free of charge to prevent various diseases)" (alágbo-òfẹ́), and Eyẹ́fodo, the powerful magician and controller of amulets and charms. All the three egúngún are an apparent example of egúngún-olóogùn, the controller/maker/provider of amulets, charms, or medicinal concoctions. There are also the àtòrì whip-flogger egúngún (egúngún-ẹlẹgba/olọreẹ), distinguished by 


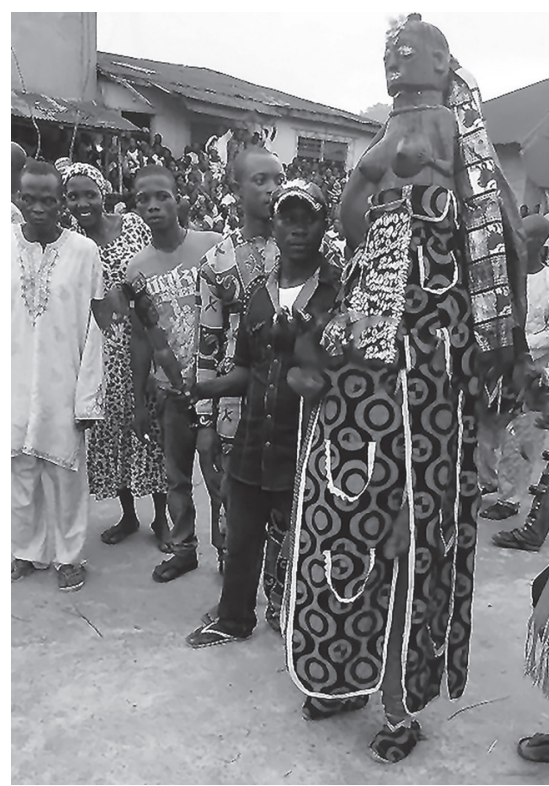

Figure 24: Olọmọ

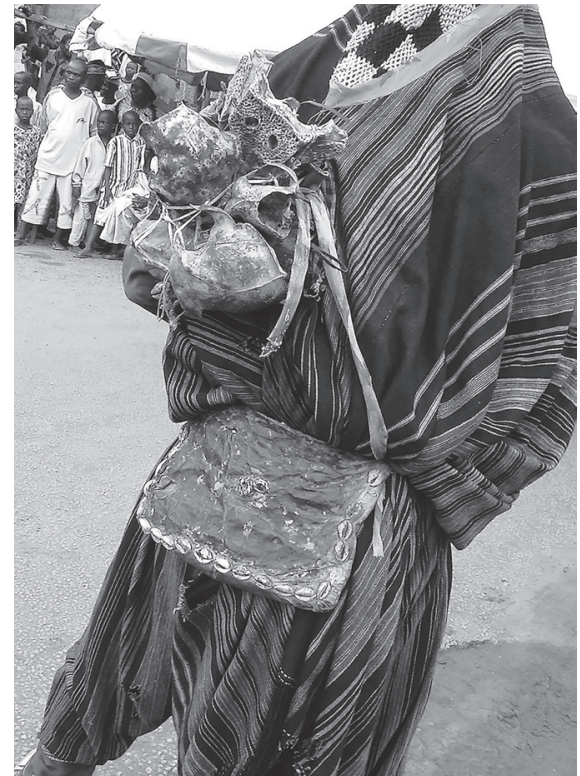

Figure 25: Alágbo-ọfẹ

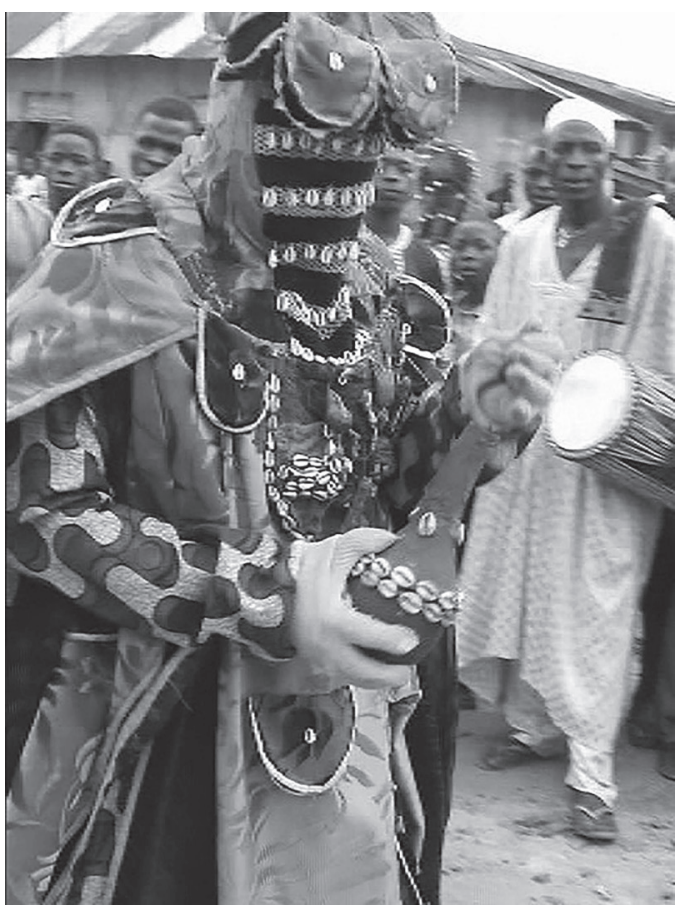

Figure 26: Eyẹ fodò 
their unchecked aggressive and chaotic character, as they whip and terrorize the whole crowd of spectators. Examples of such belligerent egúngún are Awó, Ộbọ, the Scorpion (À kèèkèé), Bólódeòkú, and the "hooligan/ragmuffin" (Jàndùkú), among others.

In the olden days when nearly all the streets of Òkèigbó were surrounded by thick forests, the preparation rite for the appearance of most egúngún (especially those distinguished by their large shroud costumes) in which the ệkú/ agọ are donned by the arệkú occurred inside the igbó-igbàlẹ. It was from the igbó-igbàlè that the egúngún emerged to the waiting crowd of adherents and spectators outside of the forest-grove. Today, only one egúngún, by the name of Aláwọpálà, still uses the igbó-igbàlè as his site of his appearance, when all the rest now appear from their individual families' "houses in heaven" (ilérun). Hence, the following oriki speaks to, and reminds us how the most celebrated egúngún (like those from the Ėsà Òggbín--a leading egúngún lineage) characteristically appeared from igbó-igbàlẹ:

Pààká di mẹfà nígbàlẹ

Ẹkú di mẹ́fà mo lò wọ́n gbó

E wá w’aṣo Egúngún bó se lu kámi lára bí ajere

Ėyin'kùnlé Olọgbiń nìgbàlè

Mo ní kílóse t'óbinrin ò m’awo?

Ará Ògbojò, wọn kiíf'ọkọ́ kan'lẹ nígbàlè

Èyí t'óbáf'ọkọ́ kan'lè nígbàlè

Óti sá bàbá ẹ l’ọ́kó

Ėmi ònífọkọ́ kan bàbáà mi

Ẹsà Ògbin, ará òde Ògbólúké

Tìgboro sẹe, tìgbàlè șé

Eégún t'óbá tìgboro șé lașo rẹ nj’òpò ọmọ láńganran

Eyí t'óbá tìgbàlè șé, a jẹ kikì așo Ẹsà Ògbín

Ọmọ Molúfọn-Adé, mo jẹ’bẹ bi ẹní jẹ’su

There are now six egúngún in our family forest-grove of egúngún

Therein we have six shroud-costumes of egúngún and I used all until they worn out

Come and look at how the egúngún shroud-costume has become tattered on my body

The forest-grove of egúngún is right there at the backyard of Olọggbin

I asked why then are females not allowed therein (at the forest-grove of egúngún)?

The natives of Ògbojò don't plow the forest-grove of egúngún with the hoe 
Whosever among them tilled the forest-grove of egúngún with the hoe That one has stroke his father with the hoe

I for one will not strike my own father with the hoe

My father Ẹsà Ògbín, resident at the compound of Ògbólúkẹ

Emerging/ appearing from the house or the forest-grove of egúngún

Any egúngún who emerged from the house is the one with a tight-fitting shroud

The one who emerged from the forest-grove of egúngún always have the voluminous shroud-costumes, which typify the egúngún Èsà Ògbín Child of Molúfọ́n-Adé, who eats the yam porridge as if it were yam

The Òkèigbó community's Odún Egúngún is an annual ritual festival that is permanently scheduled to commence on July $25^{\text {th }}$ and last for seven days. The exception is the Kúólé Ọlọjẹẹe Egungun lineage, whose family members commence their own Odún Egúngún a day prior (on July $24^{\text {th }}$ each year). This is because the Kúólé Ọlọjẹẹe are direct descendants of Ẹsà Ògbín Ológbojò, popularly known as Baba Egúngún (the overall founding father of Egúngún-Ọyọ́, from which the egúngún cult of Òkèigbó descended). Thus, the Kúólé Olộjẹẹ lineage members are given the honor of starting their own Odún Egúngún a day before the general commencement date.

Principally to facilitate their smooth performances, the ritual performance context of ơdún egúngún in Òkèigbó is segmented into four phases, namely, Ikúnlẹ̀ Egúngún; İta Egúngún; İje Egúngún, and İgbájà Egúngún, discussed as follows in that order. The discussion is followed by eyewitness accounts of an episode of the egúngún performance context, which was precipitated for the most part by the nature of the language of drum that was being drummed for the given egúngún.

\section{Ìkúnlè Egúngún}

The First day of the ọdún egúngún is called Ìkúnlẹ Egúngún (literally, the kneeling rite for Egúngún). It is so called because all the egúngún devotees must be on their knees in front of their individual family's high altar of egúngún (ojúbọ egúngún) as they invoke their ancestor spirits and petition them to banish death from their family, promote their wellbeing, and bring about the community's peace, harmony, and stability. The symbol of egúngún that is displayed on every egúngún lineage-family’s ojúbo egúngún are whips (àtòri), carved in a spiral design called isán. This is the reason ojúbo egúngún is also known as "the abode of spirally designed àtòrì/isán, symbol of egúngún” (awésàń). Thus, both ojúbọ egúngún and awésàn are used interchangeably. From the esoteric level, the isán is called "Death's whip" 
(ọpá-ikú), a short form of "the whip that we (devotees of egúngún) use to drive death away from the egúngún-lineage family compound" (òpá tí afi lé ikú ní lé Ò̀jẹ).

The following is the author's eyewitness account of the performance context of Ìkúnlẹ egúngún by the egúngún devotees from the egúngún-lineage family of Badà Esṣúbí (whose praise name is "the garment of amulets/ charms (àrán-oògùn). On Monday July 19, 2004 (five days prior to the İkúnlẹ Egúngún), a pigeon (e yẹlé) was ritually sacrificed to Oya, the goddess of the river, by means of it being slaughtered and its blood being sprinkled on the high altar of Oya (ojúbọ Oya). Next, early in the morning of İkúnlẹ Egúngún (on Sunday July 25, 2004), an offering of wraps of puréed and cooked corn starch (ẹkọ) and pureed and steamed beans (mọ́nmoọin) and kola nut (obiàbàtà) is presented in front of the isán (or ọpá-ikú) located at the family's ojúbọ egúngún/awésàn. A votive sacrifice of a rooster was made by slaugh-

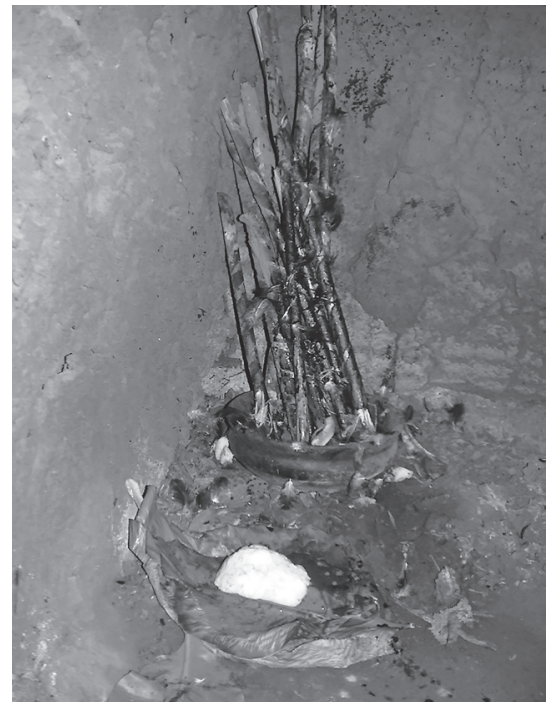

Figure 27: Ewésàán-Ojúbọ Egúngún

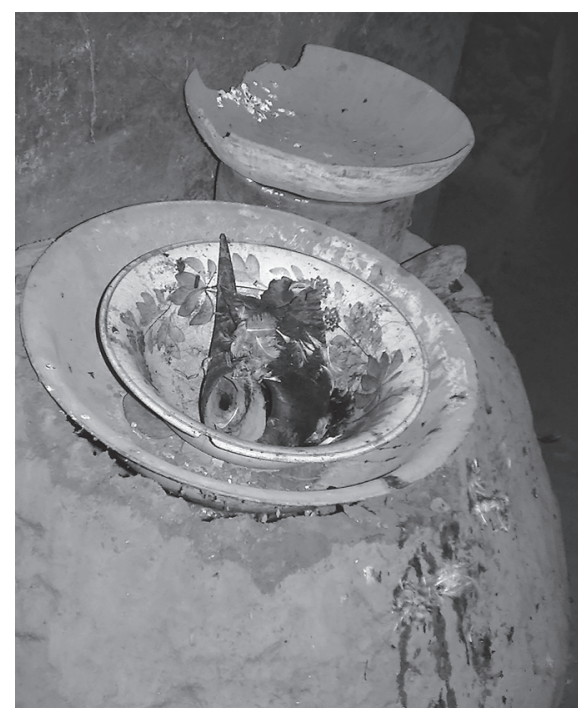

Figure 28: Ojúbọ Oya

tering and sprinkling its blood on the isán/ọppá-ikú. Describing the awésàn (ojúbọ egúngún), Bàbá Ọlộpàádé,the head of the Badà Eșúbí egúngún-lineage family, has explained that, "awésàn is the altar place/spot where the spirit of the family ancestor that is personified by egúngún is receiving the invocation of offerings presented to him by his children" (Awésàn ni ibi ti Bàbá ti ńgba $i b o$ ). After the presentation of offerings, all the devotees prayed to the family's egúngún ancestor spirit(s) and then concluded their prayers with the following petition-song: 
Báni lék kú lọ l'árùn lọ

Báni lékú lo l'árùn lo o

Báni l'ójòjò k’ó wợgbó lọ

Help us drive out death and disease

Help us drive death and disease away

Help us banish sickness into the forests for good

After this song was sung, all the devotees emerged from the awésàn (ojúbọ egúngún) into the front of the family hall (àkòdi badà), where they were received by the deafening drumbeats that were drummed by the orchestra of àyàn who played their dùndún drums to entertain the members of the Badà Ėsúbí egúngún-lineage family. All interested family members then danced in turn to the drumming as they closed the İkúnlẹ egúngún, which centered principally on the invocation (with ritual offerings) of the family's ancestor spirit(s), whose physicality is understood as egúngún. Generally speaking, it is after the completion of İkúnlè egúngún part of the annual Ọdún Egúngún that the public outings or appearances of the community egúngún, which last for seven days, would occur.

\section{Ìta Egúngún}

İta is the Yorùbá term for the "third day". As it applies to the context of the Odún Egúngún, İta Egúngún translates to all the ritual activities that are performed on the third day following the ikúnlè egúngún, the commencement of the ọdún egúngún, itself already examined. While ikúnlẹ egúngún is specifically for the invocation of the ancestor spirit(s) of the individual egúngún-lineage family, whose physical manifestation is celebrated as egúngún, ita egúngun, on the other hand, is principally for the gathering of the individual Egúngún lineage-family members to have fun and party. Therefore, ita egúngún caters to the spirit of togetherness of the family, when all members of the egúngún-lineage family, along with their invited friends and well-wishers, throw a big party in celebration and remembrance of their family ancestors.

Using the Badà Ėșúbí egúngún-lineage family's ita egúngún performance context as a case study, the following is the author's eyewitness account of İta Egúngún that this family celebrated on Tuesday July 27, 2004. At about 7 a.m., the family began its ita egúngún celebration, when all the family members converged at the Bada compound (İta Badà), where the family hall (àkòdi) is located. The àkòdì itself comprises a large hall (used for family meetings/ gatherings) and many hidden rooms dedicated to the family egúngún and 
other òrișà- related affairs/matters. First among the hidden rooms is the family awésàńlojúbọ egúngún, which has been described and analyzed under

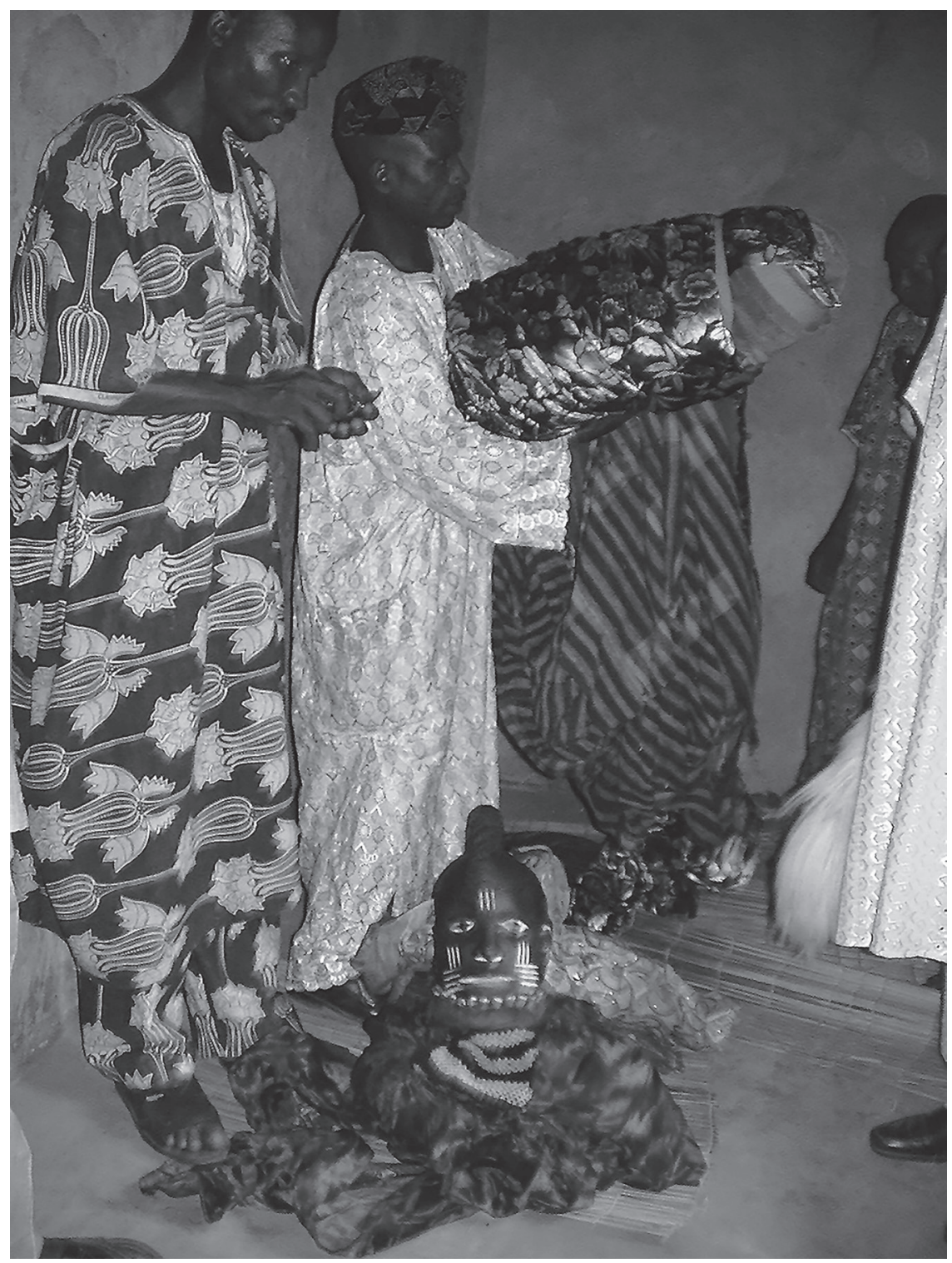

Figure 29: Ilérun

İkúnlẹ Egúngún. (See Figure 27). Another room that is much larger in size than the awésànlojúbọ egúngún inside the àkòdì is the "house in Heaven" (ilérun or ilé-Ọrun). From the functionalism approach, ilérun is a sacred room 
that has the function similar to that of a Christian sacristy (where the church's vestments and sacred vessels, among others are stored). Hence, the ilérun inside the àkòdì badà is where all the family's ẹkúlagọ are stored and donned by the arệkú during the annual Odún Egúngún. Other egúngún paraphernalia that are kept inside the ilérun in general may include those that are peculiar to, and used by, an individual egúngún àgbá, for instance, the leather belt of medicine-charm (ìgbàdí), leather underwear of amulet (ỉbàntẹ́-oògùn), leather pouches of charm (àgádágodo), sword (idà), and axe/mattock (àáké), among others.

After all the Badà Essúbí family members have converged at the ita/àkòdì badà, the young men of the house slaughtered a big goat (ewúré tío t'éwúré) that they had bought the previous day and prepared the meat. Then, the females/wives of the house (obinrin-ilé) cooked the meat, along with an array of assorted foods that included okra and meat soups (ọẹè-ilá àti ọbẹ-ẹran), pounded yam (iyán), and cassava starch meal (ẹbà). When all the food preparation was completed, everything was brought inside the àkòdi hall where all the members of the family and their invited friends and relatives, including the àyàn, had a big feast. After everyone had eaten and drunk to their satisfaction, then came the service of the àyan, who provided the drum music to which skillful dancers (among the family members) danced one after the other. At the end of the dance performances that closed the ita egúngún, I proceeded to thank Bàbá Olọpàádé, the head of the family, for having given me the privilege to partake in their family's ita egúngún ceremony. In his friendly remark, he responded, "learned person, you are the one that came at the right time. Do you also know that tomorrow is the appearance of Bàbá?" (Akọ̀wé iwo lo mọọ́ rìn. Sé o tún mọ̀ wípé ọla ni Bàbá máa jáde?). ${ }^{11}$ What the informant meant when he said I "come at the right time" was that the Odún Egúngún of year 2004, of which I partook, had been scheduled for the "appearance" of Badà (the family's most senior egúngún), since the appearance of this egúngún occurs once every other year. "Had it been that you were unlucky, you could have come last year without having the opportunity to see Bàbá" (ká ní ọdún èsí lo wá ni, o kò bátí ní ànfàní àti rí Bàbá). My informant, Bàbá Olộpàádé, concluded his pleasantry with his peculiar sarcastic laughter.

Consequently, the following is the author's eyewitness account of the appearance and performance context of egúngún Badà, which occurred on Wednesday July 28, 2004. Early in the morning, the young males of the

11 Within the context of egúngún ancestral spirits, the Yorùbá term Bàbá is understood as a physical manifestation/appearance of the spirit of the family ancestor (the example of Ancestor Badà) in the form of egúngún. The process/ procedure by which a trained arẹ̀kú, who wears the ẹkú/agò to conceal his entire body and then appears in public, takes place inside the ilérun, an allusion to the spiritual realm of spirit beings. 
family, just like they had done the day before, slaughtered another big goat in front of the family's àkòdi hall and then prepared the goat meat, which they transferred to the obinrin-ile for cooking, along with other assorted foods. The meal was meant exclusively for the family ọjẹ and also the àyàn, who provided the drumming for the egúngún. Next, the family òjẹ proceeded into the family's ilérun to prepare for the appearance of Bàbá (i.e., egúngún Badà). (See Figure 29). Because of my birthright as an ọjẹlegúngún cult member (my maternal grandfather, the late Ògúnwálé Ọdáná-Fojúràá, was of the İgbórí egúngún lineage), I had the privilege of being able to enter the ilérun with other moríwo (the male ọjẹ members) to partake in the preparation for the appearance of egúngún Badà. Following the completion of the preparation, the egúngún emerged from inside the ilérun and stepped out of the front door of the àkòdi. The Egúngún then proceeded to move very slowly as he stepped on the blood of the goat that had been spilled in front of the àkòdi building, an allusion to the ancestor's acceptance of the votive animal sacrifice. The egúngún then continued to walk very slowly, covering the entire Badà Compound (the distance of about one quarter-mile) as his royally designed long ẹkúlagọ trailed behind him like a bridal garment. As a sign of respect and also to keep the long sprawling robe moving freely, some minor egúngún entourage helped lift and align the extending robe on the floor. (See Figure $17 \mathbf{a} / \mathbf{b})$. The entire appearance and performance context of Badà took about twenty minutes before the egúngún returned to the ilérun, the spiritual realm of spirit beings to which the ancestral egúngún belong.

According to Bàbá Olọ́pàádé, "Now that the spirit of our family ancestor had been invoked and the egúngún appeared and had used his trailing ẹkú/ agọ to ward off evil and all the imminent catastrophes, no death or diseases would come near any of our family members. Surely, Baba has ushered in a year of prosperity." 12 This affirmational statement validates the significance of ọpá-ikú (derived from ọpá tí afi lé ikú nílé Òjẹ), the principal emblem of egúngún displayed on the ojúbọ egúngún that translates and alludes to "the whips that we used to drive death away from the Egúngún lineage-family compound." Accordingly, that this key symbol of egúngún is smeared with the blood of votive animals with the offering of wraps of ẹko leaves no doubt that Odún Egúngún is meant to drive death away or banish death from the homes of ọjẹ, and family devotees at large. This significance is also noticeable in Bruce G. Trigger's passing statement that "the egúngún society...was concerned with limiting the powers of death" (Trigger 2003, 500).

12 Interviews with Bàbá Ọlộpàádé (Head of the Badà Ėșúbí Egúngún Lineage), Òkèigbó. August July 19-28, 2004. 


\section{İje Egúngún}

İje is the Yoruba term for the "seventh day." As is used here within the context of the Odún Egúngún in Òkèigbó, İje Egúngún is the seventh day of activities following the commencement of the annual Odún Egúngún. Except for one exception (the compulsory Igbájà Egúngún), by tradition, Ìje Egúngún is the last day when all public appearances and performance activities of the entire community egúngún formally end for that year's Odún Egúngún. For that reason, İje Egúngún is characterized by the trouping out in a very large numbers, most if not all of the community's egúngún that have not appeared since the commencement of that year's festival. Hence, İje Egúngún is popularly described as "the day when all the egúngún have their last opportunity to fight to finish" (àjàlọ-àrùgbè egúngún), an allusion to the Egúngún making sure to complete all the activities that they needed or desired to perform, since that day is their last chance to do so.

\section{İgbájà Egúngún}

The Yoruba term Igbájà translates literally to the "market cleansing." It is an allusion to the spiritual cleansing of the community, and by extension, the whole of ayé. Hence the Yorùbá philosophical saying "the Earth is a market" (ayé lọjà). It is believed that the rite of Igbájà Egúngún is a form of an appeasement of all the community ancestors (manifested in egúngún) to ward off evil and protect all the townspeople against any imminent catastrophes like incessant death, especially of the community youths (ikú-ọwọ̀wọ́), contagious or communicable diseases (àjàkálẹ-àrùn), war (ogun), drought (ọgbẹlẹ), and

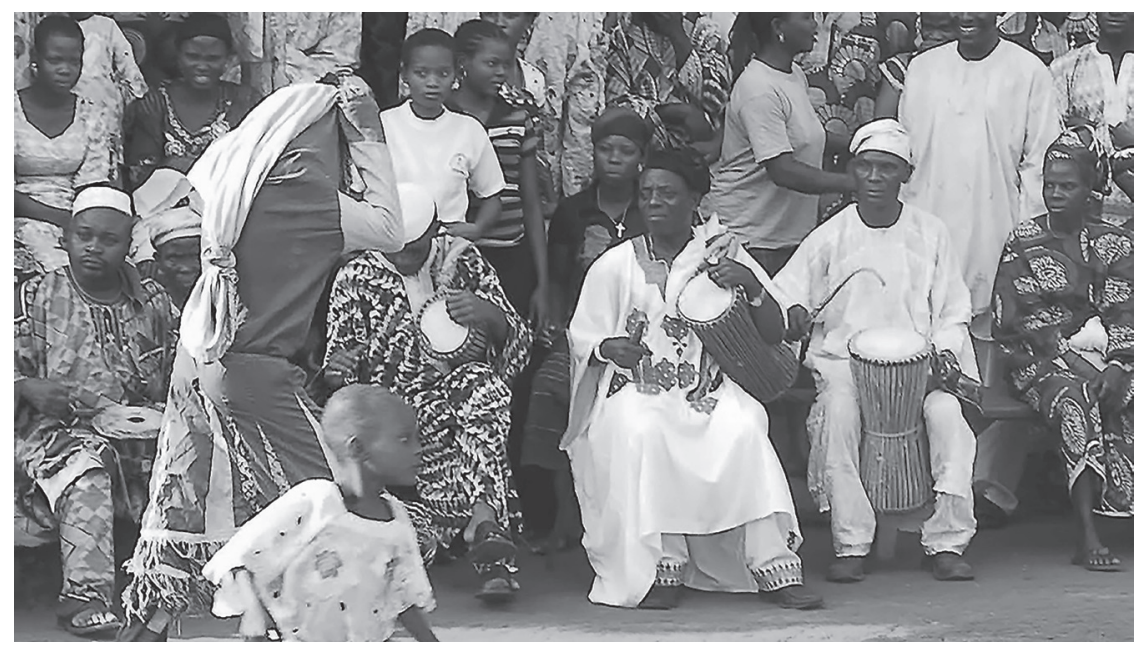

Figure 30: Onílù-Àyàn 
famine (ìyàn), among others. This last phase of Odún Egúngún is performed on İje-keji Egúngún, the $14^{\text {th }}$ day following the commencement of the annual Odún Egúngún; and is a ritual performance in which the impact of àyàn is mostly prominent. In fact, it is not an overstatement to declare that without the àyàn, who drum in their dùndún ensemble--which speaks the language of drum to which the egúngún dance performers display their dancing skills in turns--there is no Igbájà Egúngún. This grand finale rite of Odún Egúngún is when most (if not all) of the community's egúngún converge in front of the $o b a$ 's market/palace for the celebration of Igbájà Egúngún. The two groups of performers of Igbájà egúngún, whose performance contexts complement each other, are the àyàn and the community hosts of egúngún.

The author begins the Igbájà Egúngún's narrative and analysis with the professional orchestra of onílù-àyàn, who drum dùndún, the preferred drum ensemble in the performance context of Igbájà Egúngún. The reason for the preference for dùndún over any other drums, especially the bàtá, is inconclusive. However, during my interview with Pa Adésọpẹ́ İgbáladé (the custodian of Egúngún Etíyẹrí, one of the community's most senior egúngún), I was told that the egúngún's preference for a certain drum ensemble (dùndún or bàtá) is by choice and not because certain drum music or acoustic patterns are easier to dance or decode than another. He explained further that both the dùndún and bàtá are talking drums that produce an array of rhythmic patterns, which can easily be discerned and decoded by any skillful egúngún dance performer. However, I have found that there is usually only one talking drum in a dùndún drum ensemble, which is the lead drum (iyáàlù). But, in a bàtá ensemble, there could be up to three talking drums, namely, ìáàlù, omele-abo, and omele-mẹ́ta. Consequently, while a given dùndún music egúngún dancer has only one talking drum to discern and decode its language with the dance performance, on the other hand, his contemporary bàtá music egúngún dance performer must discern all the two to three talking drums' surrogate speech produced in a bàtá ensemble, in order to decode them correctly. I corroborate this point with two examples, namely: the drum's speech (the "drum language") of dùndún, and that of bàtá, discussed as follows in that order.

Example 1: Language of iyáàlù, the only talking drum (in the dùndún ensemble):

Iyaalu:

B'óbá șe pémi ni’wọ ni

Ǹbá f'apá jó, f'apá jó

B'óbá șe pémi ni’wo ni

Ǹbáf'ẹsè jó, f'ẹsè jó

B'óbá șe pémi ni’wọ ni, ǹbá fi gbogbo ara gbọ̀n rì-rì-rì-rì 
If I were you

I will dance with my hands unceasingly

If I were you

I will dance with my legs unabatedly

If I were you, I will shakeup my whole body continuously

Example 2: Language of iyáàlù, omele-abo, and omele-mẹta talking drums (in bàtá ensemble):

İyáàlu: Ọlọ́ba-níkà (Ọlọ́bańkà)

Omele-abo: Oorí

İyáàlù: Fìnkàn

Omele-abo: Oorí

İyáàlù: Fìnkàn - Fìnkàn - Fìnkàn - Fìnkàn

Omele-abo: Oorí

Omele- mẹ́ta: Ėrúkọ́ ro’ko ro’ko - Ėrúkọ yẹ̉nà yẹ̉nà - Ėrúkọ́ kọ’bè kọ’bè kọ'be

The combination of all the speeches delivered by all the three bàta talking drums:

Olọ́ba-níkà/Ọlọ́bańkà (a given egúngún)

Your wooden mask headdress

Move it sideways

Your wooden mask headdress

Move it sideways continuously

Your wooden mask headdress

Like a hoe that clears the bush without end; it cleans the footpath ceaselessly, and then makes the ridges unendingly.

\section{Analysis:}

In Example 1, the given egúngún dance performer would discern and decode (with his dance performance) the language of iyáàlù, the only talking drum in the dùndún ensemble. Whereas in Example 2, the given egúngún dance performer (Ọlọbańkà) must discern and decode simultaneously (with his dance performance) all the three bàtá talking drum's speeches (transcribed above). It is therefore reasonable to conclude that the language of the dùndún drum ensemble is more direct than that of bàtá, which may have accounted for its preference in the performance context of Odún Egúngún of Òkèigbó. 


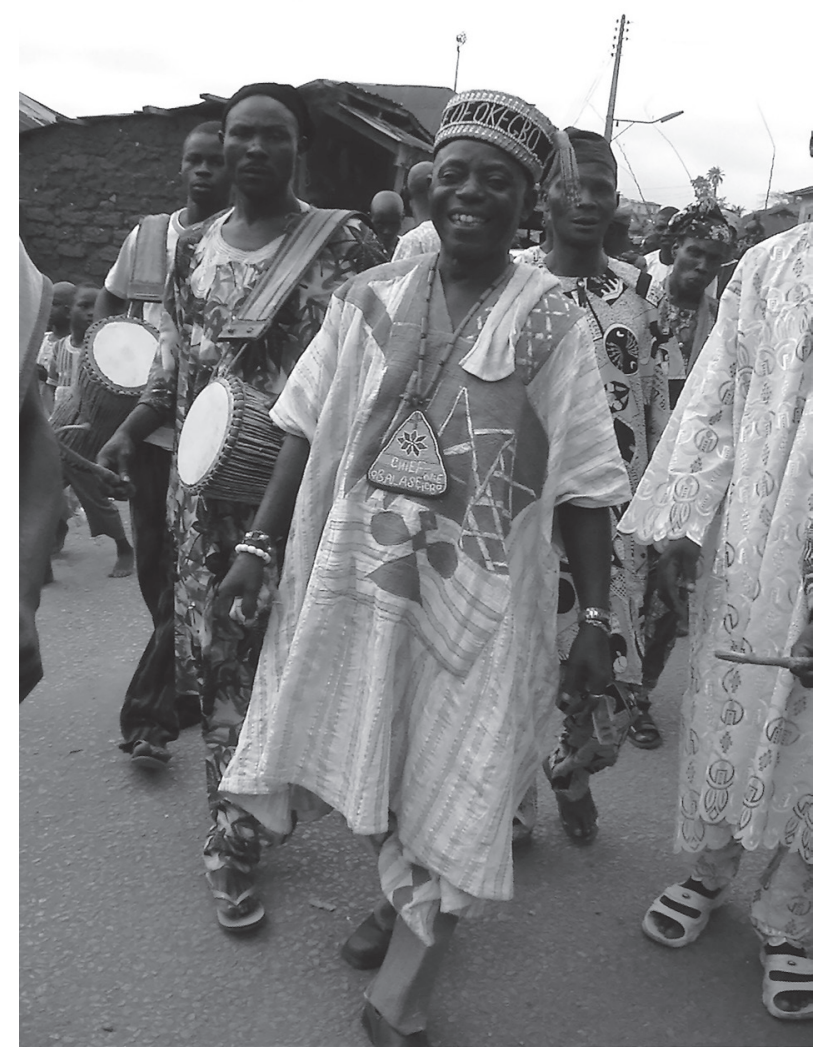

Figure 31: Photo of Chief Gbémibádé Akinròmádé

On Tuesday July 27, 2004 (eleven days before that year's İgbájà Egúngún-the grand finale of Odún Egúngún), I conducted an interview of Chief Gbémibádé Akínrọ̀mádé, the head/highest chief (ọbalásẹelbaálẹ) of the onílù-àyàn of Òkèigbó and İfẹtẹ̀dó. The subject of that interview was on the role of àyàn within the performance context of Odún Egúngún. The following are the unedited words of the interviewee, which confirmed that the indispensable role of àyàn in connection with egúngún (as in the Odún Egúngún) has been dated back to the beginning of time/existence. He said:

"In the beginning of time/existence, the egúngún were the spirit beings who brought peace and stability into the earth. When the egúngún were coming from the heaven, they first descended into the forest-grove of egúngún. As they were emerging/ appearing to the public from the forest-grove of egúngun, they stopped when they got to the entrance. It was there (at the entrance of the forest-grove of egúngún) where they were being escorted home/ to the public by the orchestra of drummers with the drumming" (Láti igbà ìwásẹ, Eégún 


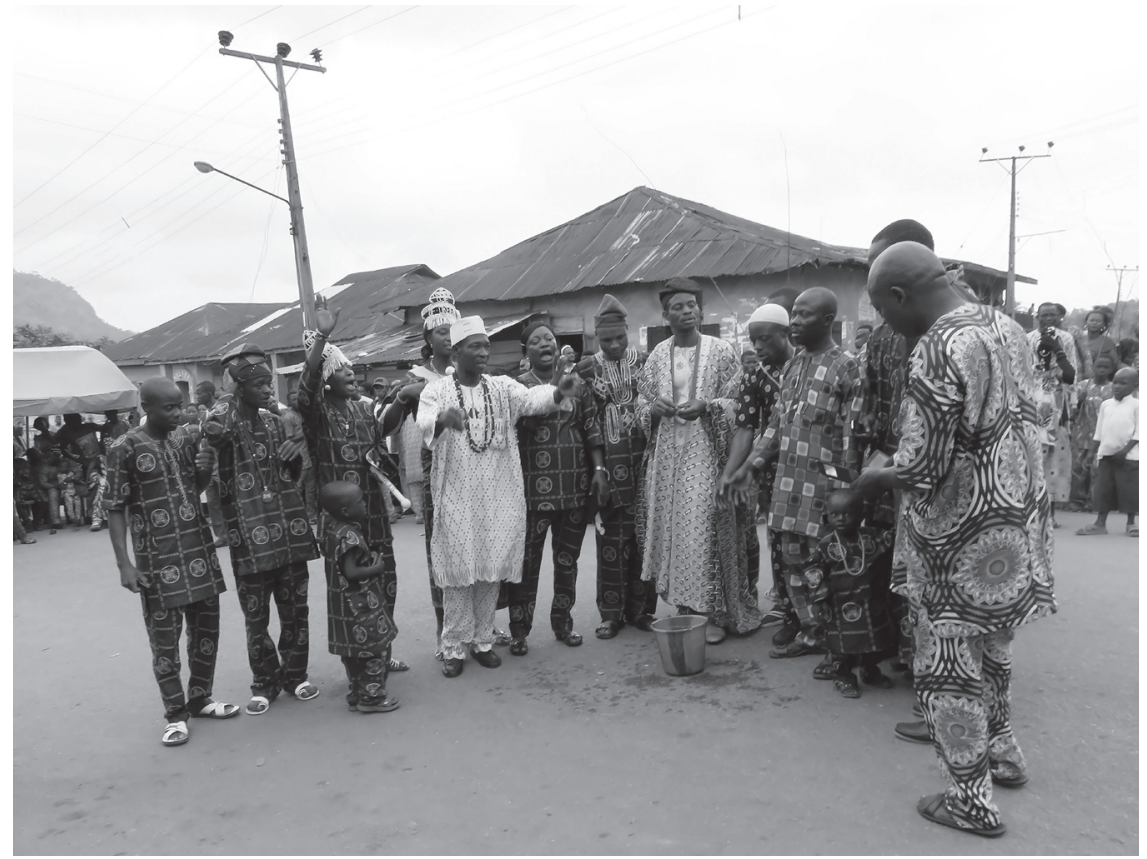

Figure 32: Purification Rite of the dancing arena-ground of Egúngún

ló m’áyé gún. Nígbà Eégún ńbọ lát'òde ọ̀run, wộn rọ̣ ka’lẹ sígbó igbàlẹ. Nígbà Eégún ńbọ láti Igbó-igbàlẹ, Eégún ló dúró kí àwọn Onílù lọ mu wá).

The interviewee explained further that since that time/day, the Àyàn have forever been drumming for egúngún. He concluded that the type of dùndún drum music that the àyàn drum for the dance performance of egúngún, especially during Igbájà Egúngún, is called gèsé, which comprises seven distinctive acoustic patterns (or rhythms), namely, elékóto, láàntòtò, ìranpá, ì ù Șàngó, ìlù Oya, ìlù Òrișà-Oko, and ìlù Ọbàtálá.

The following is the author's eyewitness account of the performance context of the Igbájà Egúngún that was held on Saturday August 7, 2004 at İtaÀàre (one of the major open-space markets/streets at Òkèigbó that is ideal for such performances). The Igbájà Egúngún started with the dancing arena's purification rite, when an offering of consecrated water was presented (by way of sprinkling on the entire dancing floor) to Ilẹ, the Earth goddess, invoking the deity to purify the ground on top of which the egúngún were scheduled to 


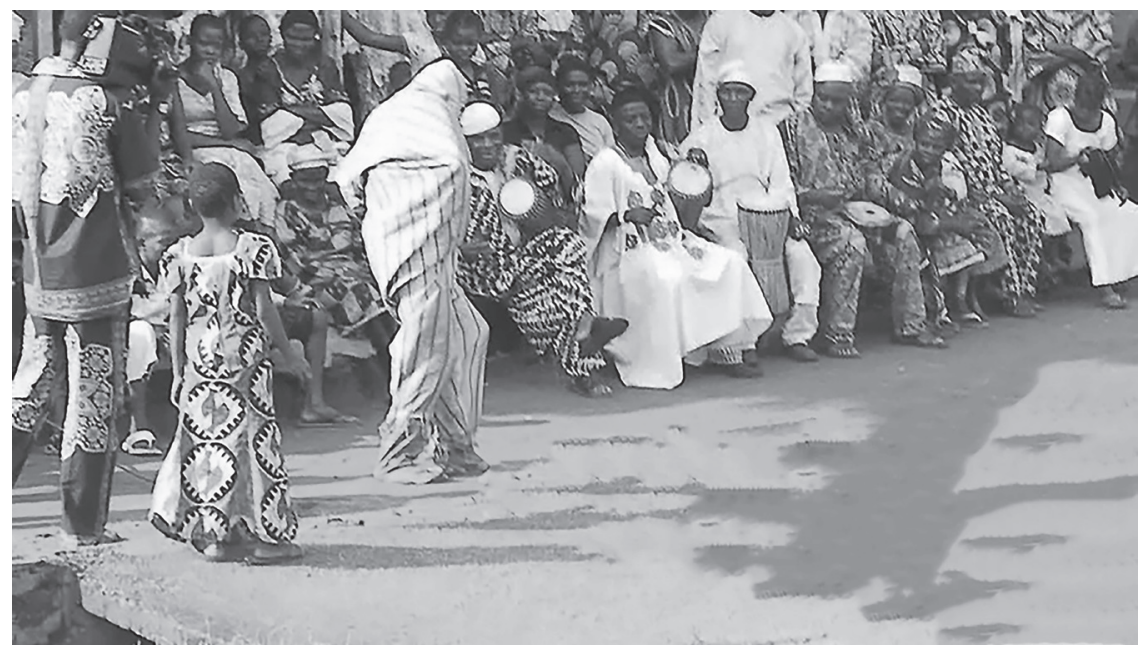

Figure 33: Egúngún Alágọ opening the floor

dance, one after the other. ${ }^{13}$ The purification rite was followed by the dance performance of Egúngún Alágọ, whose permanent duty is to open the floor of the dancing arena, dancing before the other egúngún. The reason this arrangement is so crucial is that Egúngún Alágọ is by tradition the most senior egúngún of the sayégún, whom God sent from their heavenly abode to stabilize the chaotic ilé-ayé in the beginning of time/ existence.

After Egúngún Alágọ had completed his dance performance (i.e. he had danced to all the seven drum patterns/rhythms of gèsé), all the other egúngún who wished to dance moved out to the dancing arena from their seats and displayed their dancing skills in turns. Generally, the best known and most skillful egúngún dance performer is encouraged by the aláàgbáà to dance last; the reason being that the egúngún dance performer who dances best brings that year's Igbájà Egúngún dance performance to an end. The spectators alike commend that egúngún with the accolade, "this egúngún dance performer had dismissed the crowd!" (Egúngún yií ti fộgbo o!), an allusion that that year's Igbájà Egúngún dance competition had come to an end. For that reason, the egúngún that danced last and dismissed the crowd at the Igbájà Egúngún that

13 The purification rite of the dancing arena of egúngún during İgbájà Egúngún is always led by the head of the egúngún cult (aláàgbáa), with the assistance of the rest members of the egúngún cult, who are known as the ọjẹ̀. NB: There are both male and female ọjẹ members in the cult of egúngún. However, except for one circumstance, only the male ọjẹ̀ are allowed inside the ilérun and/or igbó-igbàlẹ. And that one circumstance occurs when there is the need to lead any given female praise songs (oriki egúngún) expert chanter(s) into the family ilérun to chant their family’s oríki egúngún on the ẹkú/agọ that are kept therein. 


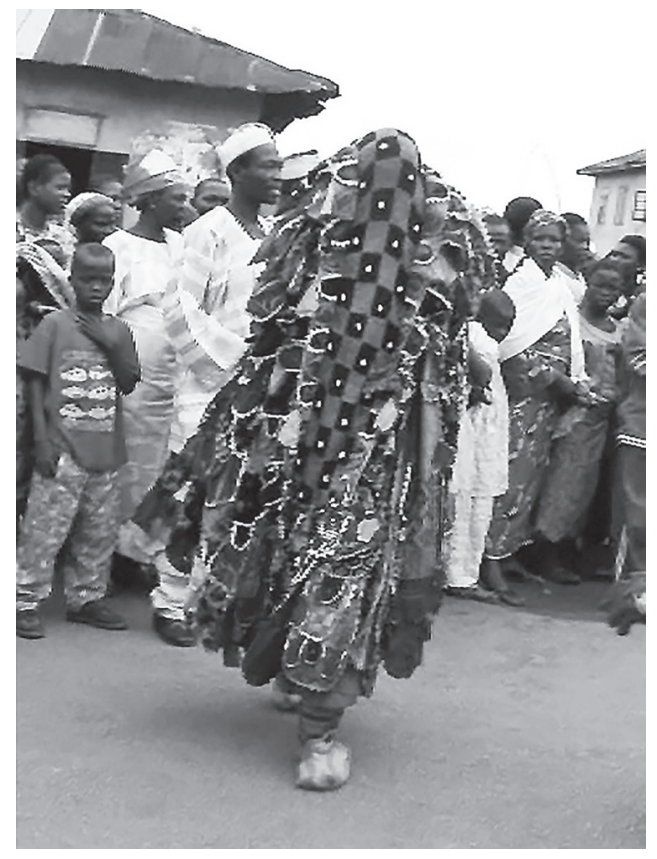

Figure 34: Bíèso-kòkó dancing at Igbájà Egúngún

was held on Saturday August 7, 2004 was said to be Bíèso-kòkó “just like the cocoa pods". The name of this egúngún is an allusion to his ẹkú/agọ costume assemblages, as they were made of carefully cut pieces of cloth of a variety of harmonious colors, each piece skillfully arranged and sewn in a symmetrical pattern. Overall, the physical appeal of Bíèso-kòkó clearly testifies to the abilities of his ẹkú/agọ shroud-costume designer as a creative artist with a high degree of mastery of all the principles and elements of design.

As the egúngún dance performers danced one after the other before Bíèso-kòkó, the best egúngún dancer dismissed the crowd and spectators, including the experienced critics among them who commented on and evaluated the performances of the àyàn, as well as the egúngún dance performers. The author begins with their evaluation of the performance context of the àyàn, who drummed the gèsé drum music with their dìndún drum ensemble. The critics used body gestures, like head nods and verbal praising, such as "may Àyàn, the god of drumming prosper/protect you!" (Àyàn ó gbè ọ́!), to reward the drummers each time they played all the seven drumming patterns/rhythms of gèsé correctly. On the other hand, if any of the seven gèsé drum music patterns/rhythms were not played correctly or when the one that was supposed 
to be drummed first does not follow suit (note: this did not occur in 2004), the critics would make such negative body gestures, such as shaking their heads.

Because the ẹkúlagọ is the sole emblem of egúngún that conceals or "kills" the human identity of the arẹk ú, and at the same time makes visible the in-

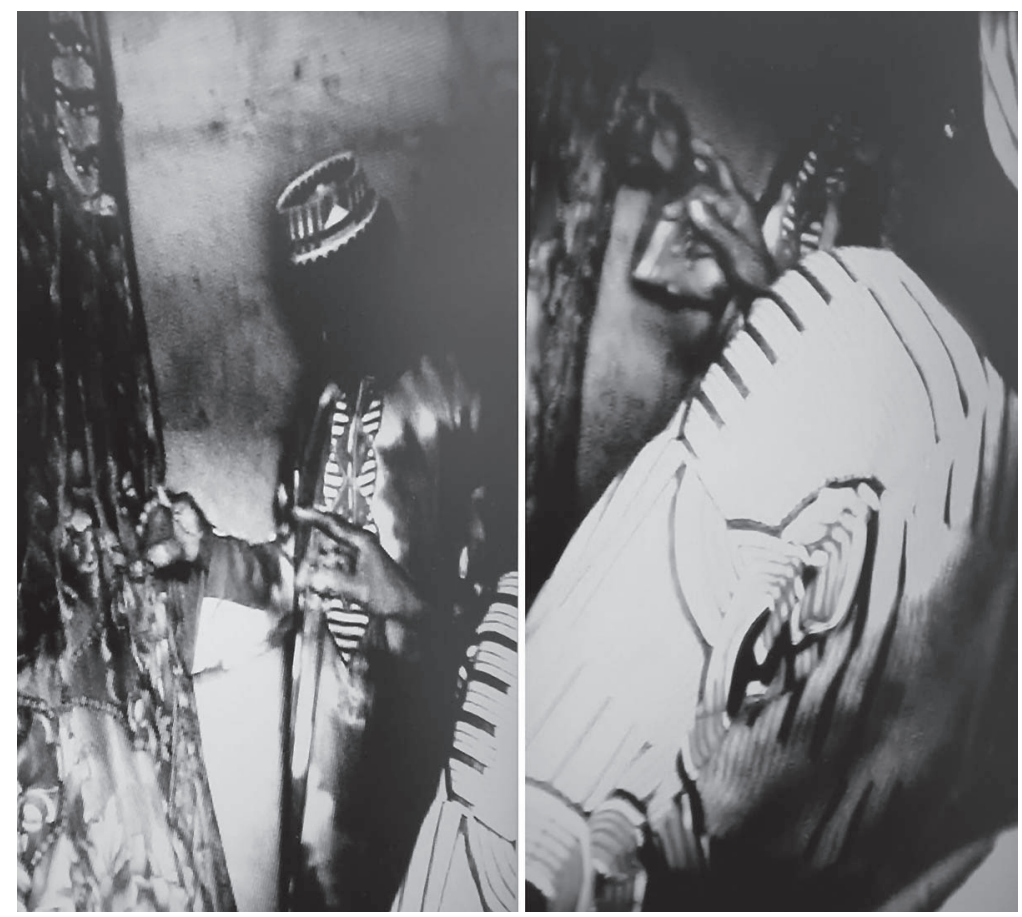

Figure 35: Mrs. Adéfúnké Àdùnní Sàádùn chanting Oríkì Egúngún Abídogun

visible spirit of the ancestor, ẹkúlagọ is therefore understood as a sacred insignia of the ancestors. In fact, to the egúngún devotees, èkúlagọ by itself is egúngún that is often referred to as "my father/ancestor" (Bàbá mi). Thus, usually during İta Egúngún in the off year in which a given egúngún will not appear in public, the elderly female children of the family ancestor egúngún known for being the best chanters of their family ancestor egúngún's oriki always go in front of their family ệkúlagọ that are displayed inside the ilérun and chant the oríki, which address the ẹkúlagọ as Bàbá mi. By tradition, that is the only one case in which any female ọjẹlegúngún cult members or devotees are allowed inside the ilérun, to chanting the family egúngún's praise songs on the ẹkúlagọ of that egúngún. The following is an example in which the oríki chanter Adéfúnkẹ Àdùnní Sàádùn (one of the daughters of Òròlú Ẹedènímọ̀bí Abídogun, the owner of Egúngún Abídogun), addresses the ẹkúl agọ of Egúngún Abídogun as Bàbá mi. 
Bàbáà mí kú ọdún òní ooo

Abídolú òòò

O kú ọún òní ooo

Abídolú òòò

Babaà mi, Aláàpẹ lóde, Abọdán rẹe

Ẹdẹmọbí, Eni t'áàá ròsé fún

Baba Adésọí, ta ńjẹ ro're tí Baba tii șe

Òròlú moò rojò

My father, happy celebration of today's festival

Abídolú (my father) greetings to you

Happy celebration to you for today's festival

Abídolú (my father) greetings to you

My father, who has an Àpẹ́ and Ọdán trees in front of his courtyard

Èdẹmọ̀bí, you are the one to whom people always relate their poverties

Father of Adésojí, has anybody ever recounted the supports that you, our father had rendered them?

Yet, father Òròlú, would never complain even when his beneficiaries don't show gratitude.

As clearly shown in this oríki, the ẹkú/agọ by itself is egúngún, and no spectators dare critique the aesthetic merits of any egúngún based on physical appearance. And also for the simple fact that egúngún is a spirit being (as is also the case among all the òrișà) whose divinity has elevated him above any mortals that could be judged, no one dares criticize any egúngún based on their physical appearance. The following egúngún-related "sacred words that must come to pass" (àfọsẹ) best illustrate this fact: "Whatsoever evil or immorality that the egúngún commit is forgiven them because of the very fact that their divinity inside the egúngún forest-grove has elevated them above all mortals; so also I must not get punished for every 'evil' that I will commit today" (B’éégún se’bi bó se’pa, Igbó-igbàlè la fi ńji; bẹeẹ gẹgé ni ohun gbogbo tí mo bá șe lónií kí ódi àṣe gbé). Babátúndé Lawal has also found another reason the Yorùbá always accept the "freakishness" or whatever evils that any òrișà (including Egúngún) do in the Yorùbá philosophical saying àditú layé: "The popular belief is that the cosmos is an unfathomable mystery (àditú) and there may be much more behind the actions of the òrișà than ordinary mortals can ever comprehend" (Lawal 2005, 166). In fact at Òkèigbó, as elsewhere in Yorùbáland, it is forbidden to even point one's fingers at any Egúngún lest speak of passing judgement.

The only exception is that the spectators can praise or criticize the family members (often called the children) of any given egúngún, whose ẹkú/agọ is 
beautiful, filthy, or raggedy, but they cannot criticize the egúngun to which the ẹkúlagọ gave form. For instance, if the physical appearance of a given egúngún is appealing, the spectators may commend his earthly children for honoring their ancestor with such an expensive cloth costume assemblage. But, on the other hand, if the physical appearance of a given egúngún is repulsive, critics may call the children of that given egúngún an array of derogatory names for their failure to show honor or respect to their ancestor, personified by the egúngún.

In contrast, because the egúngún dance performers, when honoring the ancestors (with their dance performances), also entertain the spectators at the same time, their dance performances can be critiqued. Thus, at this level (of the dance performance context), each egúngún is associated with the family owners to which he belongs. This necessitates the egúngún dance performer to display accomplished dance skills, so as not to bring shame on his family. This is reflected in the Yorùbá saying "if a given egúngún dance performer dances impressively, his lineage family-owners will feel overjoyed" (B'éégún ẹni bá jóo re, orí á yáni). By contrast, if, on the other hand, a given egúngún dance performer dances poorly, which is a demonstration of mediocrity, his lineage-family owners will be disheartened.

What constitutes an embarrassing dance performance or an impressive one? Generally speaking, the acoustic patterns of Yorùbá drumming, as earlier explicated, operate as a verbal language or speech surrogate. They are messages that are expected to be discerned or decoded and acted upon or mimed (with dance performance) by any given egúngún dance performer. Hence the reason for referring to the ilù as "talking drums." An impressive dance steps are a derivative of the egúngún dance performer's acquisition of the following aesthetic traits: patience and buoyancy (sùúrù), drumming discernible ear (etí-igbọ́lù), wisdom (ọbọ́n), insight (òye), and astuteness/cleverness (imọ̣). All these attributes of a skillful egúngún dance performer are subsumed in the Yorùbá saying "the language of drum is conveyed in proverbs; only the knowledgeable dances impressively to its acoustic patterns; while the discerning or astute individual understands or decodes its coded messages" (Bí òwe bí òwe là ńlù'lù ògìigbó; ọlọgbộn ní jo; ọmọ̀ràn nii mọọó).

For a better understanding of this, an illustration of an egúngún dance performer applying or neglecting the attributes is necessary. A given dùndún lead drummer may drum his iyáàlù (lead talking drum) to "speak" the following drum's language-speech directed to a given egúngún dance performer: "if I were you, I would dance with my hands unceasingly; If I were you I would dance with my legs unabatedly; If I were you, I would shake my whole body continuously" (B'óbá șe pe mi nìwo ni, ǹbá f'apá jó--f'apá jó; B'óbá șe pe mi nìwo ni, ǹbá f'ẹsè jó--f'ẹsẹ jó; B'óbá șe pe mi nìwo ni, ǹbá fi gbogbo ara gbọnn 
rì-rì-rì-ri). But if the poor egúngún dance performer cannot decode the message of the drum's language-speech (above), he may be doing something else, such as jumping sporadically. Whenever this happens, in order not to embarrass the egúngún dance performer or members of his family openly, the critics often do not criticize him verbally. Rather, they use body gestures, such as covering their face with the left-hand palm, closing one eye (especially the left one), shaking their heads repeatedly (sideways), and so on. The drummers too, with their drumming (or drum language), may call the egúngún dance performer an array of derogatory names, such as ikún-kò-létí, a kind of squirrel noted for its deafness, an allusion to the egúngún dance performer being deaf or novice when it comes to understanding or decoding the language of the drum. On the contrary, a skillful and experienced egúngún dance performer would respond exactly (with his dance performance) to what the language of drum asked of him. Such a terrific egúngún dance performer is accorded a loud ovation by the spectators.

However, that the egúngún dance performer must do whatever it takes to impress the spectators and bring honor to their lineage family does not mean that they should overdo the dance performance. In fact, a skillful egúngún dance performer is the one who dances moderately (ìwọ̀ntún-wọ̀nsì) and knows when to stop his dance when the ovation is loudest. The reason for this is that excessive or immoderate dancing may cause the ẹkúlagọ to fall apart and expose the egúngún dance performer's concealed human body and identity. Thus, the following Yorùbá saying speaks to such immoderation, "it is when a given egúngún dances excessively/immoderately that his waistband of charms along with his bare buttock become exposed to the public" (Ijó àjójù ní mú kí Olùwòran rí agba ìdi Egúngún). Generally speaking, the cults of egúngún all over the Yorùbáland discourage an excessive dance performance of egúngún, since it may lead to the falling apart of the ẹkú/agọ,, which conceal the unknowable as well as the human identity of the arẹkú. For that reason, a result of immoderate dance performance that leads to the exposure of a body part of any given egúngún dance performer is a grievous offence, which warrants harsh punishment. At Òkèigbó, the cult of egúngún usually bans the erring egúngún from public performance for a period of five years. In addition, certain undisclosed rituals, which would ward off the bad omens that may follow for exposing the secret (or mystery) of egúngún to the non-initiates, must be performed by the egúngún cult. Unfortunately for the blundering egúngún, he is decreed to bear the entire cost of the monetary expenses of such propitiatory ritual.

The author has mentioned that the egúngún dance performer who dances best brings the Igbájà Egúngún dance performance context for that year to an end, and that such an egúngún will be commended with the accolade Egúngún 


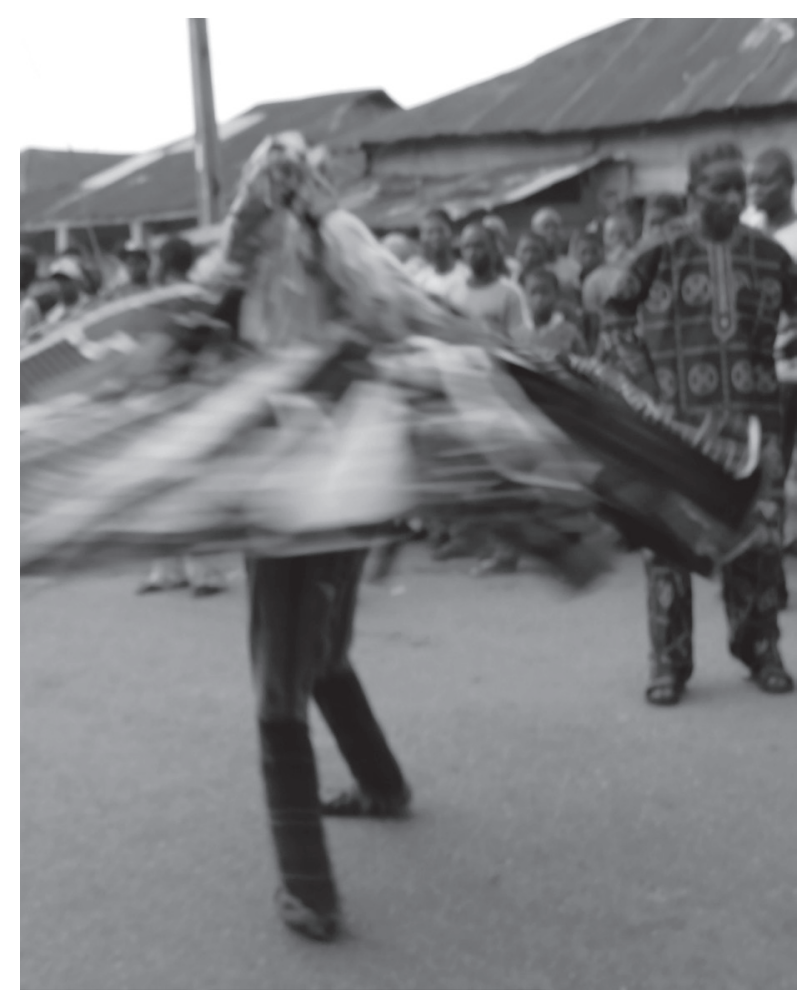

Figure 36: Adáradóhùn displaying his dancing steps at Igbájà Egúngún

yì ti fọ́gbo o! What happens after the best egúngún dance performer has dismissed the crowd? Using the İgbájà Egúngún dance competition that was held on Saturday August 13, 2016 as an illustration, the following is the author's eyewitness account of what happened after the dismissal of the crowd by Adáradóhùn (a popular egúngún that is also noted for his poetic songs), the best egúngún dance performer for that year, 2016. All the egúngún that participated in the Igbájà Egúngún (on Saturday August 13, 2016) along with their individual egúngún lineage family members held bunches of leaves in their hands, which they whisked continuously in the air, as if they were chasing away flies, as they paraded the streets. They started the parade from the $o b a$ 's marketplace (the center of the town) and ended at the outskirts of the town facing the road leading to a nearby Ondo community, where they all discarded those bunches of leaves and then retired to their respective homes. I was informed that the participants whisking bunches of leaves everywhere on the streets and later discarding the leaves in the bushes on the outskirts of the town was an allusion to the spiritual cleansing of the town, which wards off 
evil and chases away all the imminent catastrophes from the community. In this way, the market/earth cleansing (İgbájà Egúngún) is a further confirmation of Odún Egúngún as a form of ancestor veneration, a spiritual device for driving death away from the individual egúngún-lineage family compounds and promoting the wellbeing of the devotees/townspeople. It also testifies to the origin and significance of egúngún found in Odù Ọwọ̀rìn-Asẹ́yìn, which describes them as sayégún, the heavenly spirits sent by Olódùmarè to come and "stabilize the world of the living" when it was threatened with collapse.

\section{Language of Drum for Egungun as an inciting and action- prompting vehicle}

As already established in this study, the role of àyàn, who drum for the egúngún, especially during Igbájà Egúngún, and thereby provide an avenue for individual egúngún to display their dancing skills, is fundamental within the Odún Egúngún. However, it needs to be stressed that the significance of ilù as a vital Yorùbá traditional musical instrument goes beyond this level. In actuality, the drumbeats of the dìndun drum ensemble--especially those of the talking drum iyáàlù that functions as a speech surrogate, mimicking the human voice and which can therefore understood as having its own language, that of the drum--entail an action-prompting vehicle that is powerfully inciting and energizing. The author illustrates this point with the following episode of an eyewitness account, which was caused chiefly by the nature of the given language of drum (i.e. the drum's speech) that were drummed for Egúngún Aláwọpálà in the year 1912.

The episode occurred during that year's Odún Egúngún between Egúngún Aláwọpálà and Aaron Òbísẹ̀san, a Christian resident of Òkèigbó, which resulted in his death. For a better understanding of the circumstances surrounding this deadly episode, a knowledge of the background history of the religious landscape of Òkèigbó in the period (late 1800s-early 1900s) of which the episode was symptomatic, is necessary. In January 1899, when Christianity was newly brought to Òkèigbó, both the new converts and those that would not (under any circumstances) do away with their indigenous religious beliefs and practices lived together peacefully for at least a few days. However, things started to change when the town was greeted with incessant clashes between the new Christian converts and the adherents of the community's traditional religion, for instance Egúngún, Orò, Àlúkú, Edì, Olọojọ́ (also known as Ògún), among others.

Many local historians in Òkèigbó believe that the mêlées between the newly converted Christians and the community's òrìsà devotees were often caused by some of the Christian converts, who habitually seized or looted 
their family's religious carvings at night and then destroyed them, at their urging of their pastors. Actions such as these were rationalized and justified on grounds that images and idols of traditional religions needed to be destroyed so as to make sure that the "devilish beliefs and uncivilized traditions" were eradicated at once. For instance, on January 5, 1899, David Débóokú confiscated some religious carvings from his family's ojúbọ, where members of his family venerated their ancestor spirits, which he shamed and exhibited as idols in a nearby Ondo town. A few days later, on January 15, 1899, another new Christian convert--whose original Yorùbá name was Òjó Akínwándé but took the name David following his conversion to Christianity--cast into the nearby Ọni River the "Igbá Odù, which he inherited from his father...Christians broke taboos and traditions with defiance during festivals" (Babajide 2005, 64).

On that fateful day in 1912, during that year’s Odún Egúngún, as Aláwọpálà was emerging from Egúngún's forest grove (igbó-igbàlè), he was greeted/ hailed with the following drumbeats of the talking drum ìáàlù (in the dùndún drum ensemble), which carried the following action prompting message (of the language of drum) to Aláwọpálà, inciting and calling the egúngún to skirmish:

Aláwọpálà, Gbángbálà, Olóyèdé Òjè

Rùgùdú kọnrùgùdú!

İkọtún Arídà d’ogò nílé Olọttí

Ọtún Onílọkọ́, wọ́n ti múdà wọn a lèle

Òsi Onílọkọ́, wọ́n ti mú dà wọn a dẹrọ̣

Agbedegbédé Onílọkoọ, wộn ti mú dà wọn jẹrán lórí

Aláwọpálà, oò fi kọnnkọtì șa?

Eni o pé oó pa, igbàwo lo pá?

Má mà pá sí kọ̀rọ, gbangba ni o pá sí

Síọ, emi lò ńbá kiri!

Aláwọpálà, descendant of Gbángbálà and of Olóyèdé Òjẹ̣

What a brave personality!

İkọ̀tun who threatens/duns a debtor with his sword till the person settles his/her debt

The masculine-trait İlọkoọ, are brutal with the sword But the feminine-trait İlọkọ́ are soft with the sword The brave İlọkoọ that we know never hesitates to assault with the sword Aláwọ pálà, why can't you assault with your sword?

By the way, when did you kill the person you swore to kill?

Don't kill him/her in secret, you should instead kill him/her in public 
Shame on you that you have not fulfilled your promise!

As this above calling into action praise chant (oriki) that was being drummed with ìáàlù (dùndún) intensified, all the bystanders/spectators started to run away from the egúngún for fear of the imminent unpleasant reaction by Aláwọpálà, to the language of the drum, as seen above. But there was someone by the name Aaron Òbísèsan, himself a former egúngún devotee before he converted to Christianity and who therefore knew the egúngún cult's secrets, who remained unmoved. He stood in a confrontational stance in front of the egúngún (Aláwọpálà). Within a second, both had started to engage in a fight-to-finish scenario that claimed the life of Mr. Aaron Òbísèsan. This led to a big street fight that ensued between the adherents of egúngún on one side, and the Christian converts on the other side. It took the effort of the district officer at Ondo (Òkèigbó was at that time part of Ondo Province) to restore peace between the Christians and the followers of Egúngún and other forms of traditional religion in the community. ${ }^{14}$

Since then, a number of precautionary measures have been put in place, and they have proven successful many times. Among them is the designation of someone among the members of each of the egúngún lineages to serve as their family's egúngún bodygaurd (atọ́kùn egúngún), who follows the egúngún everywhere. In particular, every warrior egúngún (egúngún ológun)-- such as Egúngún Aláwọpálà, Akíngbadé, and Arọ́batẹ̀--is obliged to have an atọ́kùn egúngún. It is the responsibility of that atọ́kùn egúngún to make sure the egúngún doesn't have access to any dangerous emblems, such as weapons, belonging to that egúngún whenever being incited by the language (or surrogated speech-message) of the talking drum. An example excerpted from the earlier cited one was "Aláwọpálà, why can't you assault with your sword? By the way, when did you kill the person you swore to killl?" (Aláwọpálà, oò fi kọnk kọtì sa? Eni o pé oó pa, igbàwo lo pá?) For that reason, all the weapons owned by an individual egúngún ológun are kept only for display in the hands of the atọ́kùn egúngún. Similarly, to be an atọ́kùn egúngún required that one be very skillful when it comes to understanding and deciphering/decoding the language of the drum. So, for instance, when the talking drum says "whack or assault him/her with a weapon if he/she refuses to run away from you" ( $\mathrm{Ta}$ làbilàbi jo, b'óbá kọ̀, b'óbá kọ tì kò sá, ta làbilàbì jo), the atọ́kùn egúngún will handle the egúngún with an àtòrì, instead of an assault weapon like a machete or a sword.

14 For further reading on how Christianity came to Òkèigbó and the resulting conflicts between the new Christian converts and the practitioners of traditional religious practices in the town (late 1800s-early 1900s), see Olu Babajide, Òèigbó: A Melting Pot of Notable Towns $(2005,62-64)$. 


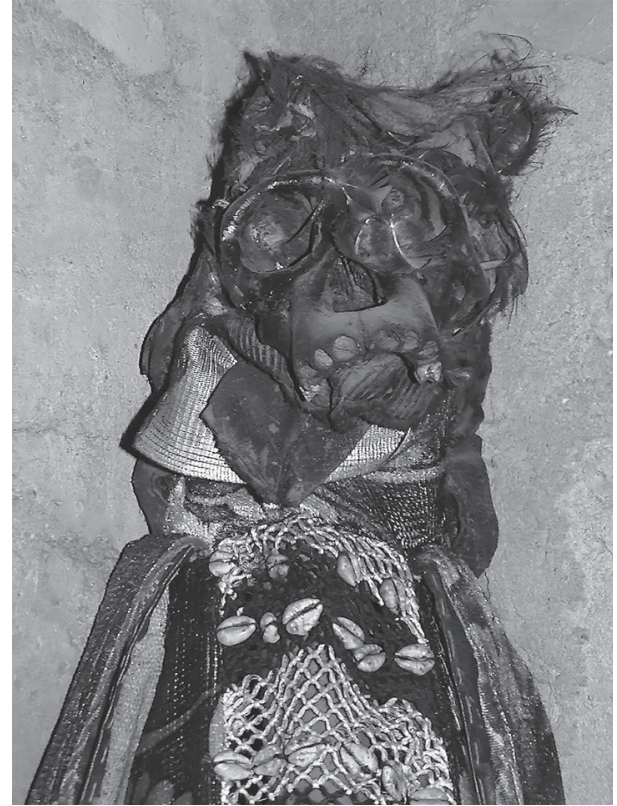

Figure 37a: Ėkú-Agò Egúngún Abídogun

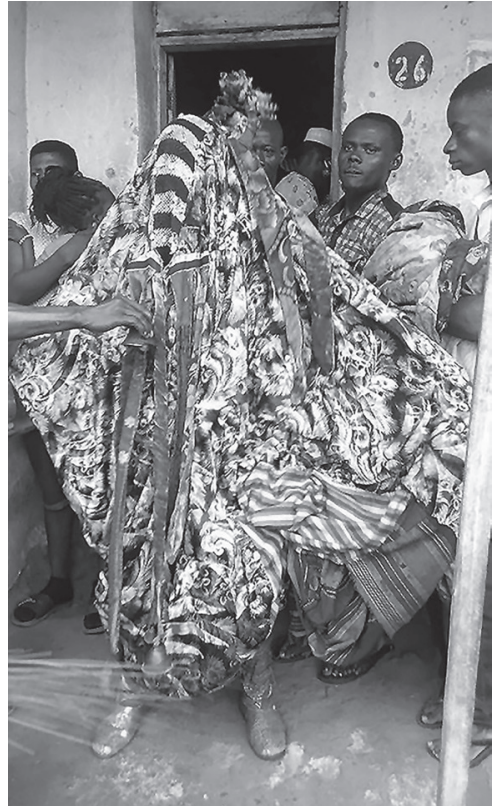

Figure 37b: Egúngún Abídogun

Another precautionary measure that I found intriguing concerns Egúngún Abídogun. Bàbá Israel Olóyèdé (aka Folly), the wearer of the shroud-costumer (àwòrò-arẹ̀kù) of Egúngún Abídogun did inform me that in the olden days, there had been no time that Egúngún Abídogun had not beheaded at least someone whenever he appeared in public every other year. That perpetual unpleasant scenario had led the family (of Egúngún Abídogun) to take drastic precautionary measures, and they redesigned the èkú/agọ of Egúngún Abídogun without the hand sleeves. Thus, now without the hand sleeves, Egúngún Abídogun was unable to handle anything, not even an àtòrì--and certainly not a sword or machete--during the egúngún's public appearance every other year. It is said that the human skull, which today adorns the headdress of Egúngún Abídogun, belonged to the last victim that he beheaded before the hand sleeves of his èkú/agọ were detached as a precautionary measure.

The final precautionary measure discussed in this study is that today (in which no one is above the law), the àyàn too are now legally (and morally) obligated to keep warning their clients (the egúngún) of the imminent danger as well as the consequences (in terms of a heavy punishment), should any egúngún carry out or put to action that which the drum's language-speech (or message) has instructed. Such warning language that the drummers get across with their talking drumbeats to their egúngún clients includes the following: 
B’óbá burú tán

İwo nikan ní ó kù

B’ộàn bá délẹ tán

İwo nikan níó kù

If you act foolishly and things get nasty afterwards

You are the only one that would face the full wrath of the law

If things get ugly and become catastrophic

You are the only one who will face the full wrath of the law

\section{Study Reflections}

As has been elucidated in this study, African art, specifically among the Yorùbá, and as Rowland Abiodun's body of scholarly works have proved, is an oríki that exists both in visual and verbal forms. This study has also added "performance," specifically the language of ìlù along with the egúngún performance actions, as the third form of Yorùbá art as oríki. Consequently, the study has established that a critical study and understanding of Yorùbá art, in addition to its "appreciation," requires the mastery of Yorùbá, the language of the people who gave the art its form and content. The study has suggested, as is also well put and illustrated in Rowland Abiodun's groundbreaking 2014 work, Yoruba Art and Language: Seeking the African in African Art, that Yorùbá art is oríki, whose history, meaning, and cultural relevance are subsumed primarily in its verbal form. Hence the need for a command or near-mastery of the Yorùbá language at the levels of speaking, writing, and reading for any meticulous study and/or better knowledge of the art. Finally, the study has also established the relationship existing between the àyà and egúngún, a form of ìwà that exists in the ẹhìn-ìà, and can always manifest in physical form through a religious device called Odún Egúngún, which is fundamental to the understanding of the art and ritual of egúngún.

\section{Works Cited}

Abiodun, Rowland. 2014. Yoruba Art and Language: Seeking the African in African Art. New York: Cambridge University Press.

Asabioje, Afenapa (And Her Traditional Ifa/Orișa Bata Musical Band). 2007.

Album "Isese Lagba" (Tradition and Culture Is the Best). Duration: 54:42 minutes (the "Ogboni" track is 7:01 minutes).

Babajide, Olu L. 2005. Okeigbo: A Melting Pot of Notable Towns. Ile-Ife: S. O. Popoola Printers.

Bascom, William. 1952. Drums of the Yoruba of Nigeria. New York: Folkways Records \& Service Corp. 
Beier, Ulli. 1964. “The Agbegijo Masquerades,” Nigeria Magazine (82): 191-192.

Bascom, William. 1969. Ifa Divination: Communication between Gods and Men in West Africa. Indiana: Indiana University Press.

Daramola, Olu ati A. Jeje. 1967. Awon Asa ati Orisa Ile Yoruba. Ibadan: Onibon-Oje Press.

Drewal, Margaret Thompson. 1997. "Dancing for Ogun in Yorubaland and in Brazil," 199-234. In Africa's Ogun: Old World and New (Second Expanded Edition), Edited by Sandra T. Barnes. Indiana: Indiana University Press.

Euba, Akin. 2011. "Review Work: Bata by Amanda Villepastour," Ethnomusicology 55(3): 516-520.

Famule, Olawole F. 2003. EGBE OGBONI: The Yoruba Council of Elders, It's Origins and Artistic Relevance. Master's thesis. The University of Arizona, Tucson Arizona.

Famule, Olawole F. 2005. Art and Spirituality: The Ijumu Northeastern-Yoruba Egungun. Ph.D. dissertation, the University of Arizona. UMI Dissertation Services, Ann Arbor, Michigan.

Famule, Olawole. 2017. "Masks, Masque, and Masquerades," 389-406. In Culture and Customs of the Yoruba. Edited by Toyin Falola and Akintunde Akinyemi. Austin, TX: Pan-African University Press.

Heyden, Marsha V. 1977. “The Epa Mask and Ceremony," African Arts X(2): $14-21$.

Lawal, Babatunde. 2005. "Divinity, Creativity and Humanity in Yoruba Aesthetics," Literature \& Aesthetics: the journal of the Sydney Society of Literature and Aesthetics (SSLA) 15(1): 161-174.

Ojo, J.R.O. 1973. “Ogboni Drums,” African Arts 6(3): 50-52.

Omojola, Bode. 2010. "Rhythms of the Gods: Music and Spirituality in Yoruba Culture," The Journal of Pan African Studies 3(5): 29-49.

Pemberton III, John. 1989. "The Oyo Empire." In Drewal, Henry John, et al. Yoruba: Nine Centuries of African Art and Thought, ed. Allen Wardwell, 147-187. New York: Center for African Art and Harry N. Abrams, Inc.

Trigger, Bruce G. 2003. Understanding Early Civilizations: A Comparative Study. New York: Cambridge University Press.

Villepastour, Amanda. Ed. 2015. The Yoruba God of Drumming: Transatlantic Perspectives on the Wood That Talks. Jackson: University Press of Mississippi. 